Bedim, B.P., Campos, C.F.; Vidal, T.C. Equipamentos turísticos do Parque Estadual do Itacolomi (MG): análise das instalações e dos atrativos construídos. Revista Brasileira de Ecoturismo, São Paulo, v.3, n.2, 2010, pp.283-314.

\title{
Equipamentos turísticos do Parque Estadual do Itacolomi (MG): análise das instalações e dos atrativos construídos
}

\author{
Bruno Pereira Bedim, Caiki Flaeschen de Campos, \\ Tatiana Corrêa Vidal
}

\section{RESUMO}

A pesquisa analisa os atrativos turísticos construídos que compõem a oferta agregada do Parque Estadual do Itacolomi (MG), incluindo os equipamentos, a estrutura de comunicação do parque e as formas de estímulo à visitação, propondo alternativas de otimização do uso dos mesmos. Foram levantados dados empíricos sobre a superestrutura turística e sobre os componentes operacionais do Programa de Uso Público deste Parque Estadual. A partir da metodologia de inventário, procedeu-se à categorização dos meios de hospedagem (área de camping e alojamentos), alimentos e bebidas, eventos, serviços, transportes, edificações, instalações e atrativos culturais. Diagnostica-se uma concentração geográfica de tais equipamentos na Zona de Uso Intensivo do Parque, a qual se torna cada vez mais frequentada à medida que o mesmo foi aperfeiçoando suas construções e elaborando novos atrativos adequados a um perfil emergente da demanda turística.

PALAVRAS-CHAVE: Equipamentos turísticos, Atrativos construídos, Parque Itacolomi.

Tourist equipments of Itacolomi Park (Minas Gerais - Brazil): analyze of facilities and built touristic attractions

\section{ABSTRACT}

This research analyzes the built touristic attractions that make up the aggregate supply of Itacolomi State Park (MG), including equipments, the communication structure of the park and ways to stimulate visitation by proposing ways to optimize its use. Empirical data were collected about infrastructure supporting tourism, superstructure and operational components of the State Park Public Use Program. From the inventory methodology, researchers categorized the types of accommodation (camping area and housing), food and drinks, events, services, transportation, buildings, facilities and cultural attractions. They also diagnosed a geographical concentration of those equipments on the Intensive Use Zone of the park, which becomes more and more crowded as it has improved its buildings and developing new suitable attractions to an emerging profile of touristic demand.

KEYWORDS: Tourist Equipment, Attractive Built, Itacolomi Park, SWOT Analysis 


\section{Introdução}

A visitação pública em parques nacionais e estaduais vem produzindo e organizando espaços de lazer diferenciados. Segundo Bedim e Tubaldini (2006), a zona de uso intensivo de um parque aberto à visitação pública, via de regra, pode ser entendida enquanto espaço organizado e apropriado a partir de demandas externas, articulando a si a lógica da simulação, um espaço diferenciadamente produzido para ser consumido sazonalmente pelos visitantes. A racionalidade do "uso" destes recursos por populações urbanas, subjugadas ao modo de produção e às ideologias e aparatos políticos dominantes, engendram a transformação das práticas sociais de apropriação da natureza (BEDIM, 2007; 2009).

O turismo, por sua vez, se apresenta enquanto fator (re)estruturante das práticas espaciais nos parques - haja vista a implementação de atrativos turísticos construídos, cujo uso condiciona-se aos enquadramentos da apropriação públicoprivada e a acessos diferenciados funcionalmente.

Em termos gerais, Cooper et. al. (2007) definem que os atrativos construídos são aqueles que compõem a oferta turística agregada e estão, via de regra, relacionados à história e à cultura dos lugares, podendo estes serem prédios, igrejas, ruínas arqueológicas, palácios, casas ou até cidades. Se essas construções estão em desuso, podem ser adaptadas para o mercado turístico. Além dos atrativos turísticos históricos, há, também, os construídos com a funcionalidade específica de entretenimento, podendo ser incluídos os parques temáticos e de lazer, locais destinados ao esporte, acampamentos, colônias de férias, teatros, dentre outros.

Frederico e Neiman (2010) observam que, via de regra, as instalações turísticas em áreas naturais são de tamanho reduzido. Os autores apontam a emergência de fatores como a personalização no atendimento ao cliente, e ainda, que o perfil do ecoturista não se limita mais aos tradicionais "mochileiros", constituindo-se, pois, de um público cada vez mais exigente e preocupado com os impactos ambientais da construção das instalações turísticas.

Nas Unidades de Conservação (UC's) que permitem acesso total ou parcial ao público, existem diversos tipos de atrativos construídos; dentre eles podemos citar como exemplo a abertura de trilhas temáticas, deques, churrasqueiras, etc. Os equipamentos e atrativos turísticos localizados no interior dos parques visam a agregar valor e atratividade aos recursos naturais disponíveis na Unidade, podendo muitas vezes agregar valor educativo também. No Brasil, autores como Serrano (2000), Neiman e Rabinovici (2010) tem dedicado especial atenção às pesquisas envolvendo a interface entre turismo e áreas naturais protegidas, pontuando inclusive a importância das Unidades de Conservação no sentido de instrumentalizar a educação ambiental dos visitantes.

O foco deste artigo, contudo, é analisar as funcionalidades e entraves à gestão dos equipamentos e atrativos turísticos do Parque Estadual do Itacolomi. Ao final, propõe-se um roteiro de análise destas instalações, no sentido de subsidiar o seu adequado planejamento e gestão. 


\section{Metodologia}

O artigo consiste em uma pesquisa empírica baseada no estudo de caso da oferta turística do Parque Estadual do Itacolomi (PEIT). Adota-se o modelo de diagnóstico da EplerWood International (2007), articulando-o à proposta do inventário do MTUR - Ministério do Turismo - e a metodologia SWOT, além de pesquisa junto à biblioteca do Parque Estadual do Itacolomi; coleta e análise de dados quantitativos e qualitativos junto à administração do parque; pesquisa no Plano de Manejo do PEIT; trabalho de campo e análise "in loco" de todos os seus atrativos turísticos construídos. Os dados empíricos foram coletados entre julho e outubro de 2009.

As técnicas de investigação consistiram, ademais, no exame da documentação por meio de consulta a arquivos do Parque Estadual do Itacolomi (documentos oficiais) para obtenção de cópias do Projeto de Criação do Parque (1967), do Anteprojeto do Plano de Manejo (1993), do Pré-Zoneamento Ecoturístico, do Inventário da oferta turística, de Manuais e Folhetos. A pesquisa bibliográfica consistiu no levantamento de conceitos, diretrizes e normas que regem o Sistema Nacional de Unidades de Conservação - SNUC, além de obras que possibilitassem estudar a ocupação da área ao longo do processo histórico. Tais bibliografias foram disponibilizadas pelo órgão administrador do parque, no caso o Instituto Estadual de Florestas, através de seu acervo bibliográfico.

\section{Caracterização da área de estudo}

O Parque Estadual do Itacolomi apresenta uma das mais significantes amostras dos ecossistemas característicos da Serra do Espinhaço ${ }^{1}$; abriga espécies de animais e vegetais raras, ameaçadas de extinção e/ou endêmicas, e serve como área de procriação de espécies de aves migratórias - além de conter alguns dos primeiros afluentes formadores da Bacia do Rio Doce, que são de importância fundamental para o abastecimento de água das cidades de Ouro Preto e Mariana.

Ademais, este parque integra o turismo no chamado Circuito do Ouro - situado no eixo central da Estrada Real em Minas - sendo o único parque estadual aberto à visitação pública na Região dos Inconfidentes - oferecendo novas opções de lazer para a população circunvizinha à UC e aos turistas em geral.

A localização do Parque é privilegiada por abranger a maior parte da Serra do Itacolomi, a qual é um dos componentes do limite sul da Cadeia do Espinhaço, a mais antiga formação geológica do Brasil (TERRA, 1994). O ponto culminante do parque é o Pico do Itacolomi, com 1772 m de altitude - o qual, segundo Bedim (2004), serviu de referencial geográfico para os primeiros bandeirantes paulistas que chegaram às regiões auríferas no final do século XVII.

O Parque Estadual do Itacolomi possui um grande potencial turístico - ainda não de todo explorado - combinando relevantes valores históricos, culturais, ecológicos e cênicos. Segundo Bedim (2004, p.5): 
Por volta de 1698, o Pico do Itacolomi serviu de marco geográfico para os primeiros bandeirantes que adentravam pela região em busca de metais preciosos. Ao longo do período colonial, muitas histórias tiveram como palco as grandes fazendas com terras dentro dos limites do Parque, em especial a Fazenda São José do Manso, Fazenda do Cintra e Fazenda do Cibrão. Entre as heranças dessa época, figura a Casa Bandeirista, cuja construção é atribuída a Domingos da Silva Bueno - $2^{\circ}$ Guarda-Mór do Distrito de Minas Gerais - entre os anos de 1706 e 1708 para cobrança de quintos, vigilância e defesa do acesso às minas de Vila Rica. Trata-se de uma das mais antigas construções do Estado de Minas Gerais. Essa combinação de fatores históricos contribuiu para que o parque fosse, recentemente, incorporado ao roteiro "Estrada Real" - o maior projeto turístico do Brasil, que explora turisticamente os caminhos reais que serviam de vias autorizadas de acesso à região das minas de ouro e diamante (BEDIM, 2004, p.5).

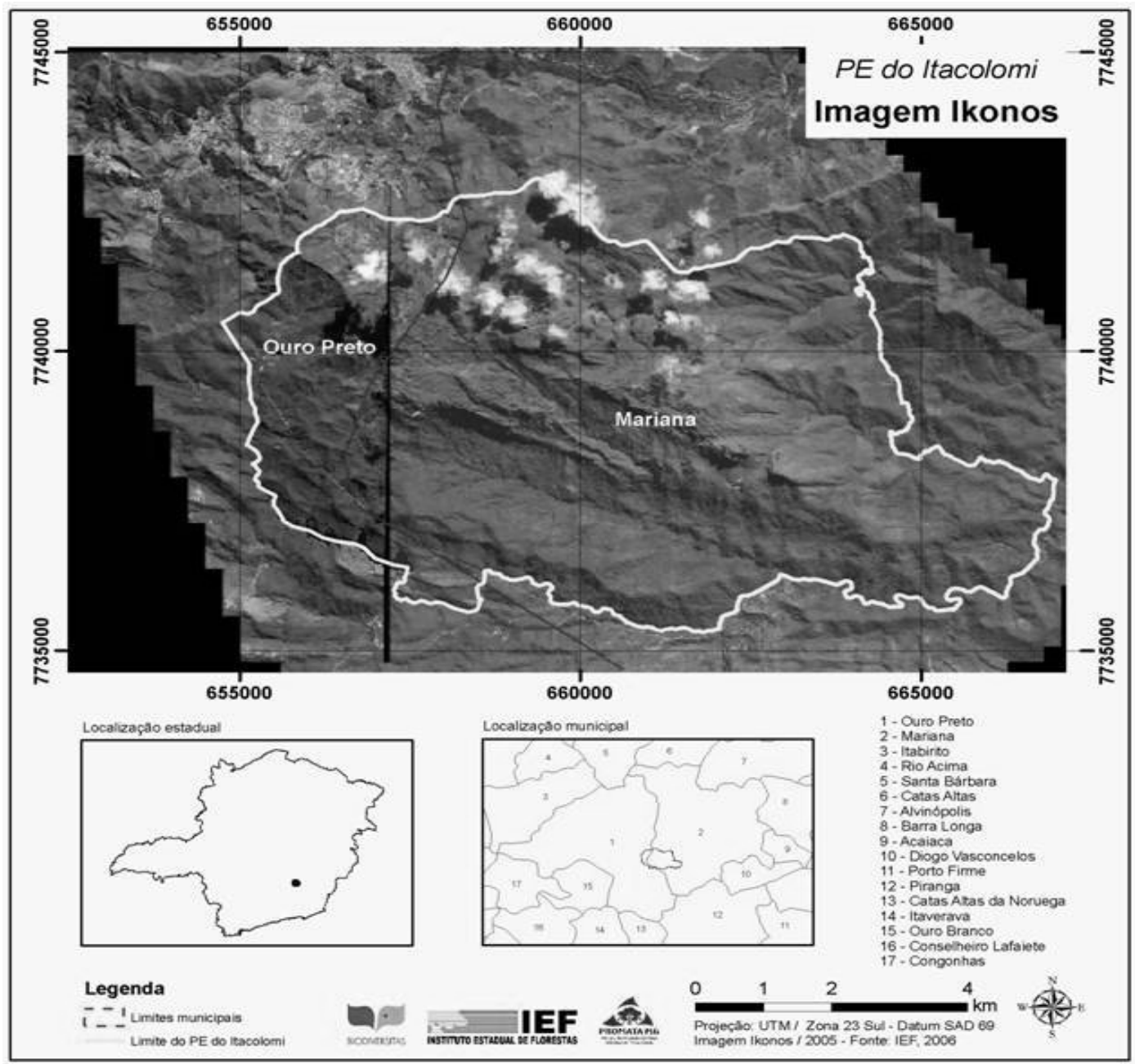

Figura 1: Limites do Parque Estadual do Itacolomi. Fonte: Plano de Manejo do PEIT, Encarte 2 Planejamento e manual de gestão, Belo Horizonte, Outubro de 2007. 
Bedim, B.P., Campos, C.F.; Vidal, T.C.

Nos 7.543 hectares do Parque Itacolomi, há uma variedade de formas paisagísticas de beleza cênica, grutas, cachoeiras, campos de altitude com afloramentos rochosos e diversos micro-biomas característicos de Mata Atlântica, Cerrado, Campos Rupestres e Zona de Transição (ecótonos).

\section{Aspectos administrativos e organizacionais}

O Parque Estadual do Itacolomi foi criado pela Lei Estadual $n^{\circ} 4.493$ de 14 de junho de 1967, e é uma importante Unidade de Conservação do Estado de Minas Gerais, cuja administração é de responsabilidade do IEF - Instituto Estadual de Florestas ${ }^{2}$. Porém, entre 2004 e 2009, a gestão operacional do turismo no PEIT foi realizada por um convênio que visava à gestão compartilhada da visitação, conforme trataremos a seguir.

A sede administrativa do parque situa-se na Fazenda São José do Manso, local que já abrigou, na década de 1930, uma fábrica de chá preto. Hoje a infraestrutura é utilizada para atender aos visitantes, contando com Alojamentos, Auditório, Biblioteca, Museu do Chá, Casa Bandeirista, Lanchonete, Centro de Visitantes, Almoxarifado, Lavanderia, Parque infantil, Camping, Estrutura de apoio ao camping, portaria, Centro de informações, churrasqueiras, Capela São José e bases de apoio para Tirolesa.

A notável beleza cênica de suas paisagens aliada à riqueza histórico-cultural de seu território conferem ao Itacolomi um grande potencial ecoturístico, que somente nos últimos anos está sendo explorado através de um Programa de Turismo implantado desde 30 de abril de 2004, que objetiva à visitação de uso público nesta Unidade de Conservação de forma organizada e sustentável, com um modelo experimental de gestão compartilhada.

Contudo, Bedim (2004) $)^{3}$ ressalta que desde 1986 o IEF/MG planejava abrir o parque à visitação, já que naquele ano foi elaborado o Plano de Implantação do Parque, dispondo sobre sua situação legal, localização e limites, incluindo também um Programa de Uso Público (IEF, 1986). Este documento abordava ainda a importância do parque no contexto local, regional e nacional. É desse período a construção da infraestrutura básica do parque (BEDIM; RAMOS, 2005).

Mas a abertura do parque ao público efetivou-se somente em abril de 2004, através do PROTUR-PEIT - Programa de Turismo do Parque Estadual do Itacolomi, um modelo experimental composto de fases sucessivas de implantação, cuja gestão foi compartilhada, a princípio, entre o Instituto Estadual de Florestas (IEF/MG), a UFOP - Universidade Federal de Ouro Preto - e a Fundação Educativa de Rádio e Televisão de Ouro Preto/FEOP. (BEDIM; RAMOS, 2005).

A partir do início de 2009, porém, uma nova parceria de gestão compartilhada foi firmada entre a ADOP - Agência de Desenvolvimento Econômico e Social de Ouro 
Preto - que assumiu o operacional de gestão do turismo no parque - e o IEF/MG, o qual prossegue sendo o responsável pela gestão técnica da conservação ambiental.

\section{Acesso e meios de transporte}

O acesso principal ao parque ocorre entre as cidades de Ouro Preto e Mariana, pela Rodovia dos Inconfidentes (BR-356). A portaria do parque é limítrofe à zona urbana da cidade de Ouro Preto e está localizada a 101 km da capital mineira Belo Horizonte. Existem outras vias secundárias de acesso que são pouco utilizadas.

O Parque do Itacolomi compõe o entorno de duas importantes cidades históricas da Região dos Inconfidentes: Ouro Preto e Mariana - cidades tombadas na categoria de monumento mundial e nacional, respectivamente. Segundo Bedim (2004, p.5), "tal posição privilegiada aliada à existência de monumentos históricos de grande significado conferem ao Parque do Itacolomi considerável valor histórico, cultural e turístico". Além disso, a ocorrência de ecossistemas típicos deste trecho da Serra do Espinhaço marcam sua importância ecológica.

$\mathrm{Na}$ via principal de acesso ao parque observa-se em todo trecho da portaria até ao complexo de visitação, placas informativas e educativas direcionadas aos visitantes. Atualmente, o transporte da portaria até o centro de visitantes fica a cargo do próprio visitante.

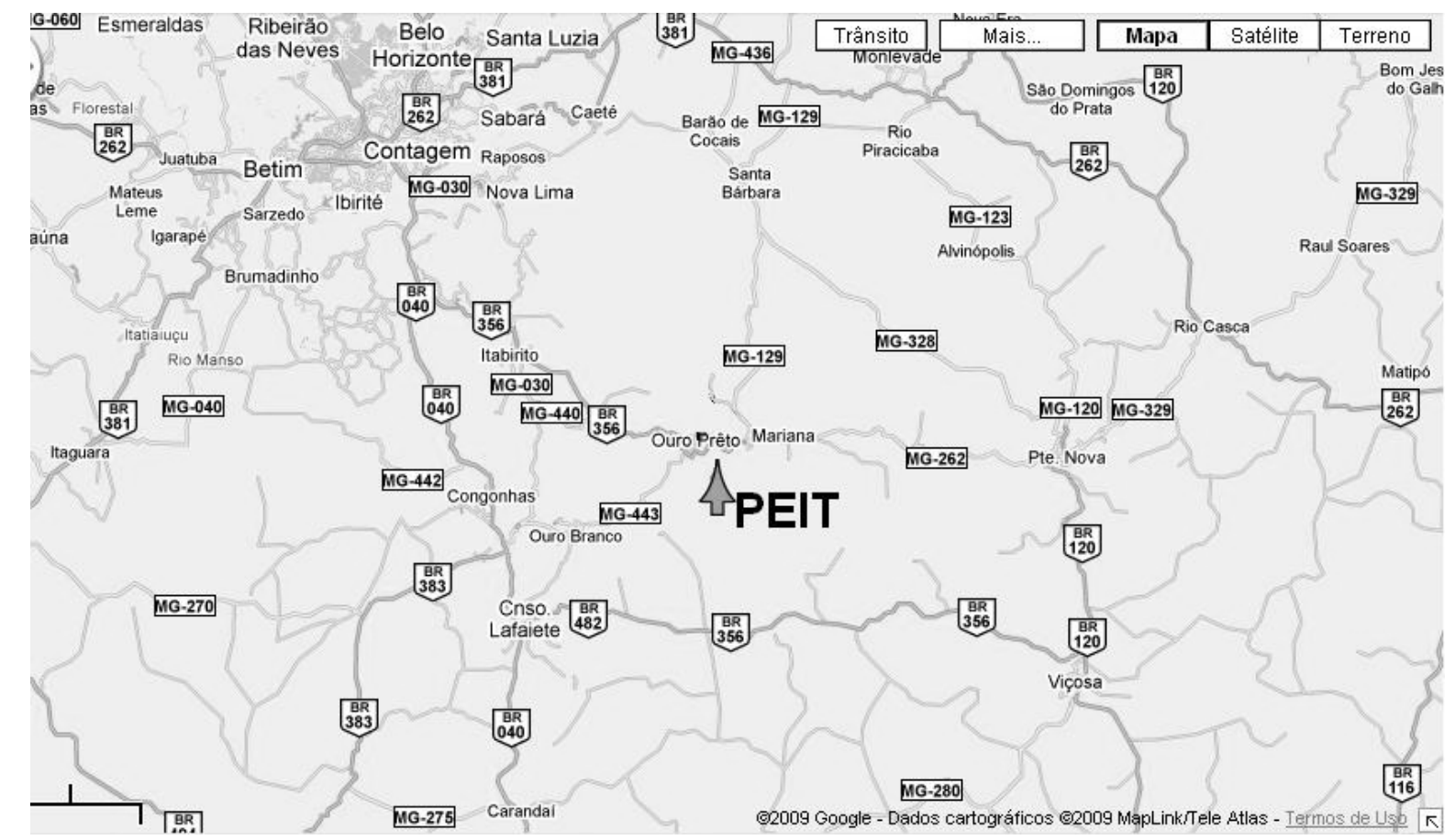

Figura 2: Localização e principais acessos rodoviários ao PEIT.

Fonte: www.googlemaps.com.br - Adaptação do autor 


\section{Caracterização dos equipamentos e instalações turísticas}

O Plano de Manejo do Parque Estadual do Itacolomi foi realizado em 2007 e o divide em sete zonas diferentes, onde se encontram, dentre outros, todos os equipamentos e instalações voltados para atender ao visitante. Estas zonas possuem normas específicas que as regem e norteiam a visitação e o uso das mesmas.

O zoneamento do Parque não menciona os atrativos construídos do parque exceto os históricos -, por isso incluiremos, nas análises, cada atrativo analisado nas zonas que se sobrepõe aos mesmos.

O mapa de zoneamento do Parque Itacolomi define, ao todo, sete zonas - intensiva, conflitante, especial, extensiva, histórico-cultural, primitiva e zona de recuperação - cuja delimitação espacial pode ser observada na Figura 3:

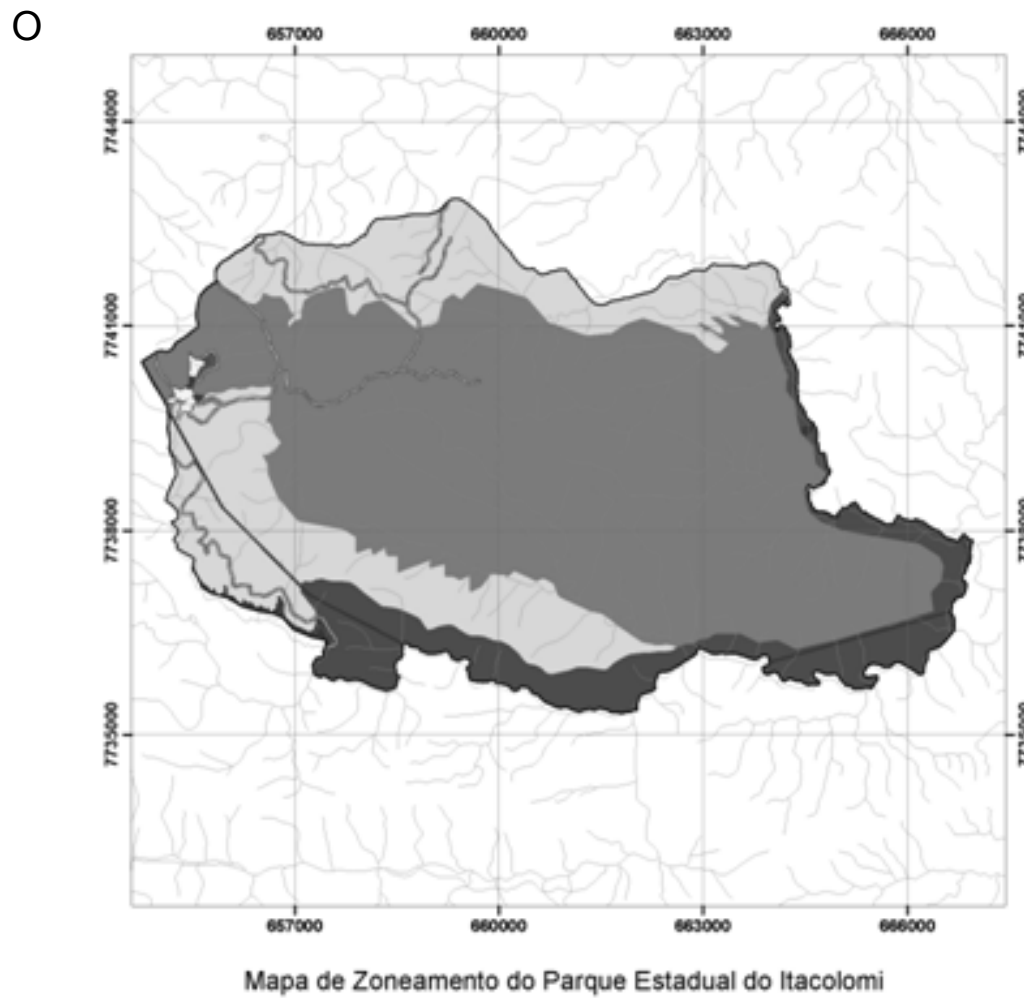

Figura 3: Zoneamento do PEIT. Fonte: Plano de Manejo do PEIT (2007).
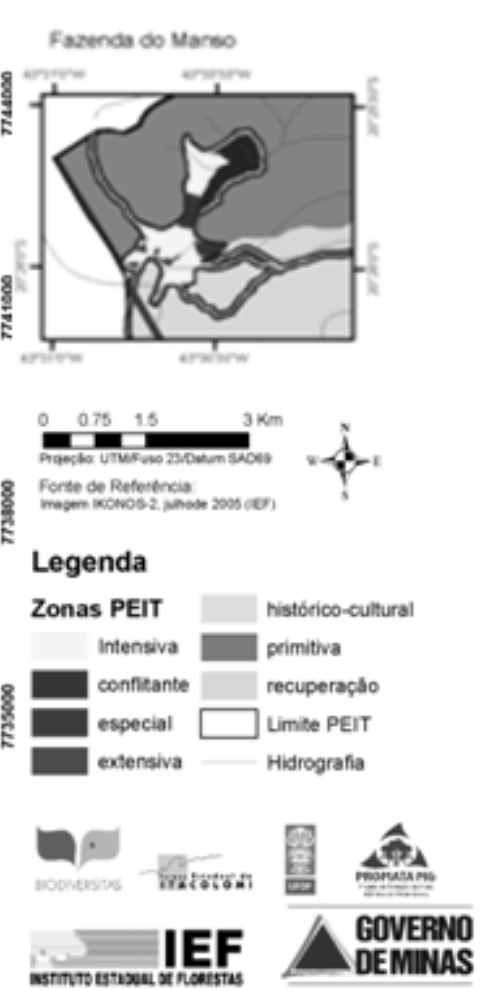

IFi- 
(Plano de Manejo do PEIT, Encarte 2 Planejamento e manual de gestão, Belo Horizonte, Outubro de 2007):

\section{- Zona de uso extensivo}

É aquela constituída em sua maior parte por áreas naturais, podendo apresentar algumas alterações humanas. Caracteriza-se como uma transição entre a zona primitiva e a zona de uso intensivo. (Plano de Manejo do PEIT, Encarte 2 Planejamento e manual de gestão, Belo Horizonte, Outubro de 2007.)

\section{- Zona de uso intensivo}

É aquela construída por áreas naturais ou alteradas pelo homem. $O$ ambiente é mantido o mais próximo possível do natural, devendo conter: centro de visitantes, museus, outras facilidades e serviços. (Plano de Manejo do PEIT, Encarte 2 Planejamento e manual de gestão, Belo Horizonte, Outubro de 2007.)

\section{- Zona de uso especial}

É aquela que contém as áreas necessárias à administração, manutenção e serviços da Unidade de Conservação, abrangendo habitações, oficinas e outros. Estas áreas serão escolhidas e controladas de forma a não conflitarem com seu caráter natural e deve localizar-se, sempre que possível, na periferia da unidade de conservação. (Plano de Manejo do PEIT, Encarte 2 Planejamento e manual de gestão, Belo Horizonte, Outubro de 2007.)

\section{- Zona histórico-cultural}

É aquela onde são encontradas amostras do patrimônio histórico cultural ou arqueopaleontológico, que serão preservadas, estudadas, restauradas e interpretadas para o público, servindo a pesquisa, educação e uso científico. (Plano de Manejo do PEIT, Encarte 2 Planejamento e manual de gestão, Belo Horizonte, Outubro de 2007.)

Estão inseridos nestas zonas os seguintes equipamentos e instalações: 
Centro de Visitantes: Possui um auditório com capacidade para cerca de 100 pessoas, equipado com data-show e demais equipamentos para a realização de palestras e apresentações públicas como cadeiras, mesa e sistema de som. Possui ainda um centro de informações dotado de painéis diversos e várias salas e equipamentos interativos que visam a passar ao visitante os programas oferecidos na Unidade e os atrativos disponíveis à visitação, além de expor os propósitos da criação do parque. É do Centro de Visitantes que saem os monitores para acompanhar os visitantes em suas caminhadas pela Unidade. O Centro de Visitantes e seus atrativos internos demandam a presença constante de um monitor. Está inserido nas zonas de uso intensivo e histórico-cultural do parque, conforme classificação presente no Plano de Manejo da Unidade (Figura 4).

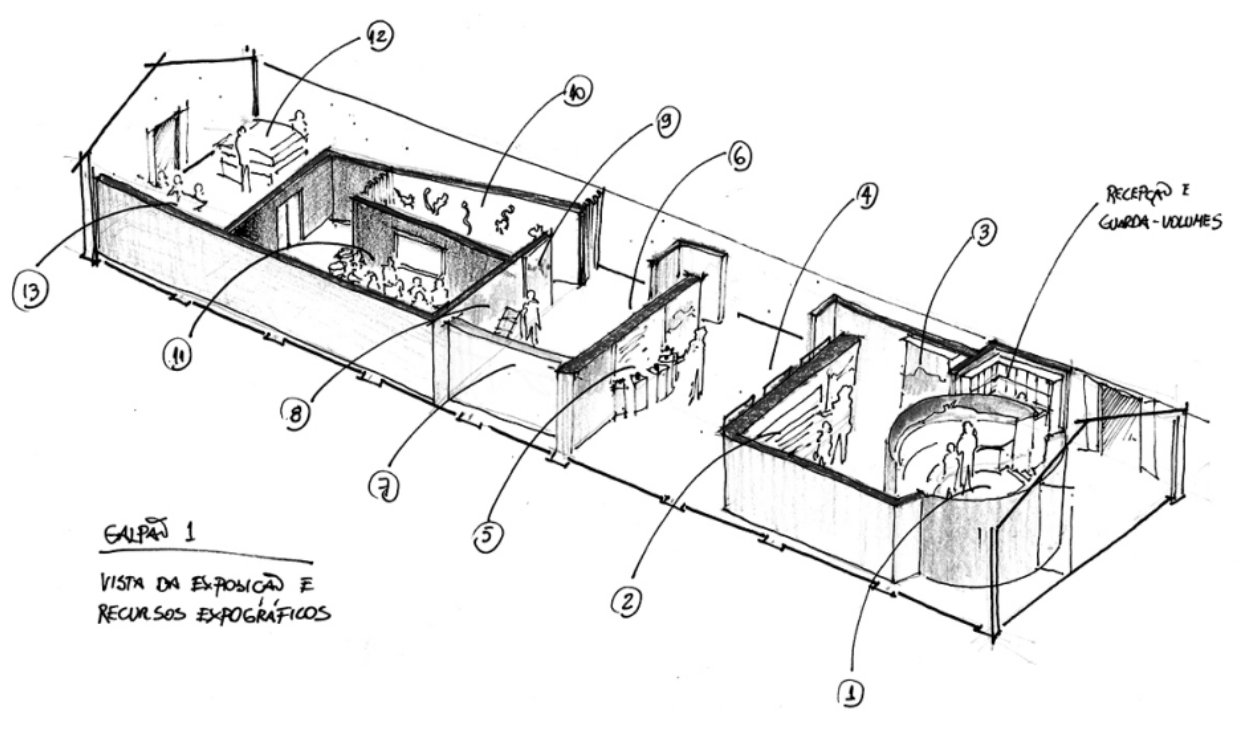

Figura 4: Parte interativa do centro de visitantes. Fonte: IEF (2007).

Área de camping: é uma área bem estruturada, que suporta até 30 barracas. A área compreende uma estrutura de suporte que contém banheiros com chuveiros, área de lava-pratos e o terreno destinado à montagem de barracas. Pode ser encontrado próximo a essa área um restaurante que também funciona como lanchonete, quatro churrasqueiras cobertas com capacidade total para 60 pessoas, parque infantil em eucalipto tratado, estacionamento e um heliporto. $O$ ingresso do camping pode ser pago tanto antecipadamente como na saída do parque após a utilização sendo que o valor do camping é de $R \$ 12,00$ por pessoa durante a semana e $R \$ 15,00$ por pessoa du- 
rante fins de semana e feriados. Um monitor permanece na área durante todo o dia. A área de camping encontra-se na zona de uso intensivo do PEIT.

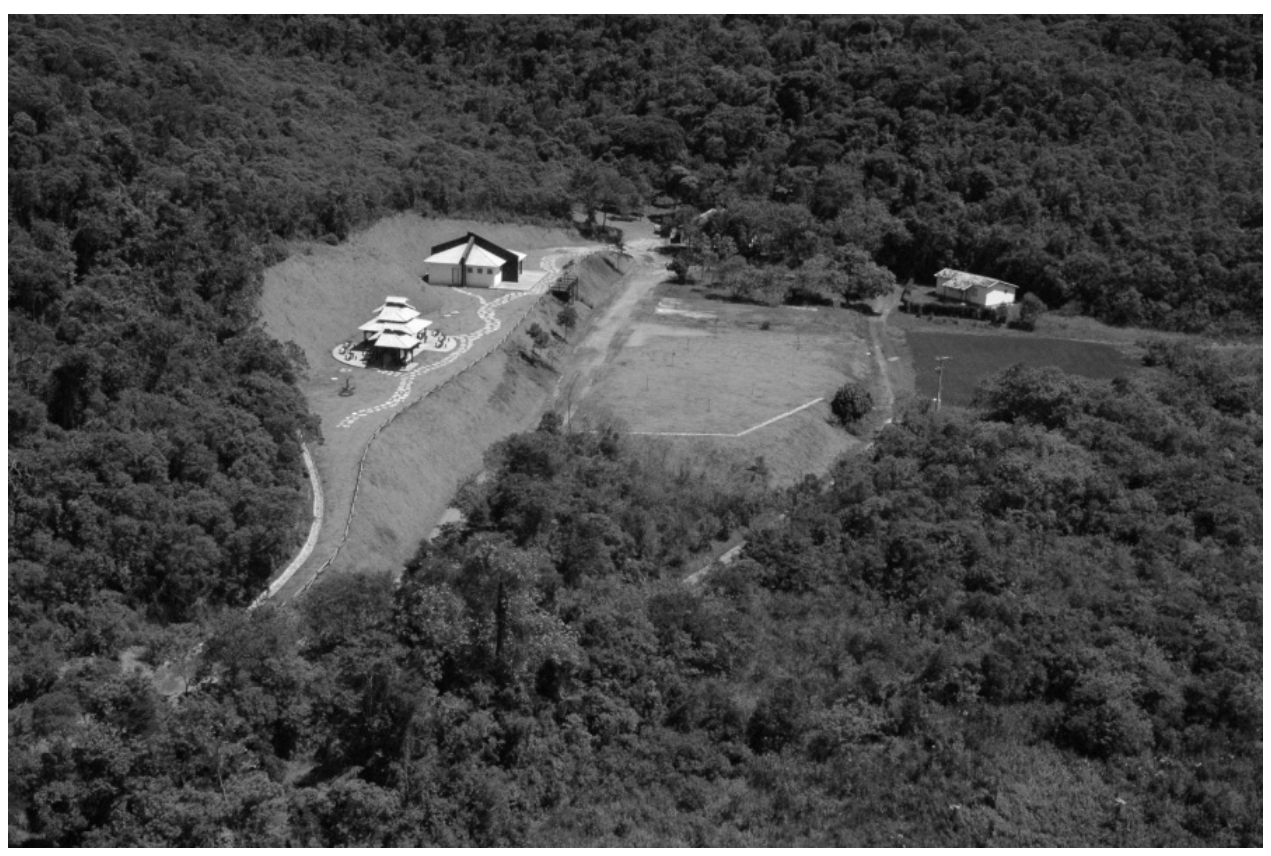

Figura 5: Vista aérea do complexo da área de camping. Fonte: IEF/PEIT (2007)

Alojamento e Casa de Hóspedes: O Parque Estadual do Itacolomi conta com cinco alojamentos, cada um com dois quartos - cada quarto possui dois beliches, sendo a capacidade de cada alojamento de oito pessoas - um banheiro com Box e chuveiro elétrico, sala/cozinha com fogão, pia e geladeira e área de serviço com tanque e varais; e uma casa de hóspede que possui quatro quartos (sendo um deles uma suíte), sala cozinha e banheiro. Há também, próximo aos alojamentos, a casa do pesquisador, com as mesmas características do alojamento, servindo para hospedar pessoas que vão ao parque com o intuito de pesquisá-lo. O alojamento, a casa de hóspedes e a casa do pesquisador não dispõem de monitores e encontram-se na zona de uso especial do parque.

A casa de hóspedes é gratuita para pesquisadores e é necessário realizar um agendamento prévio para sua utilização. Os alojamentos do PEIT possuem dois preços diferenciados de acordo com o número de pessoas que comportam. A diária do alojamento de 1 a 4 pessoas custa 120 reais e de 5 a 8 pessoas 200 reais sendo também necessário o agendamento prévio para sua utilização.(Figura 6). 


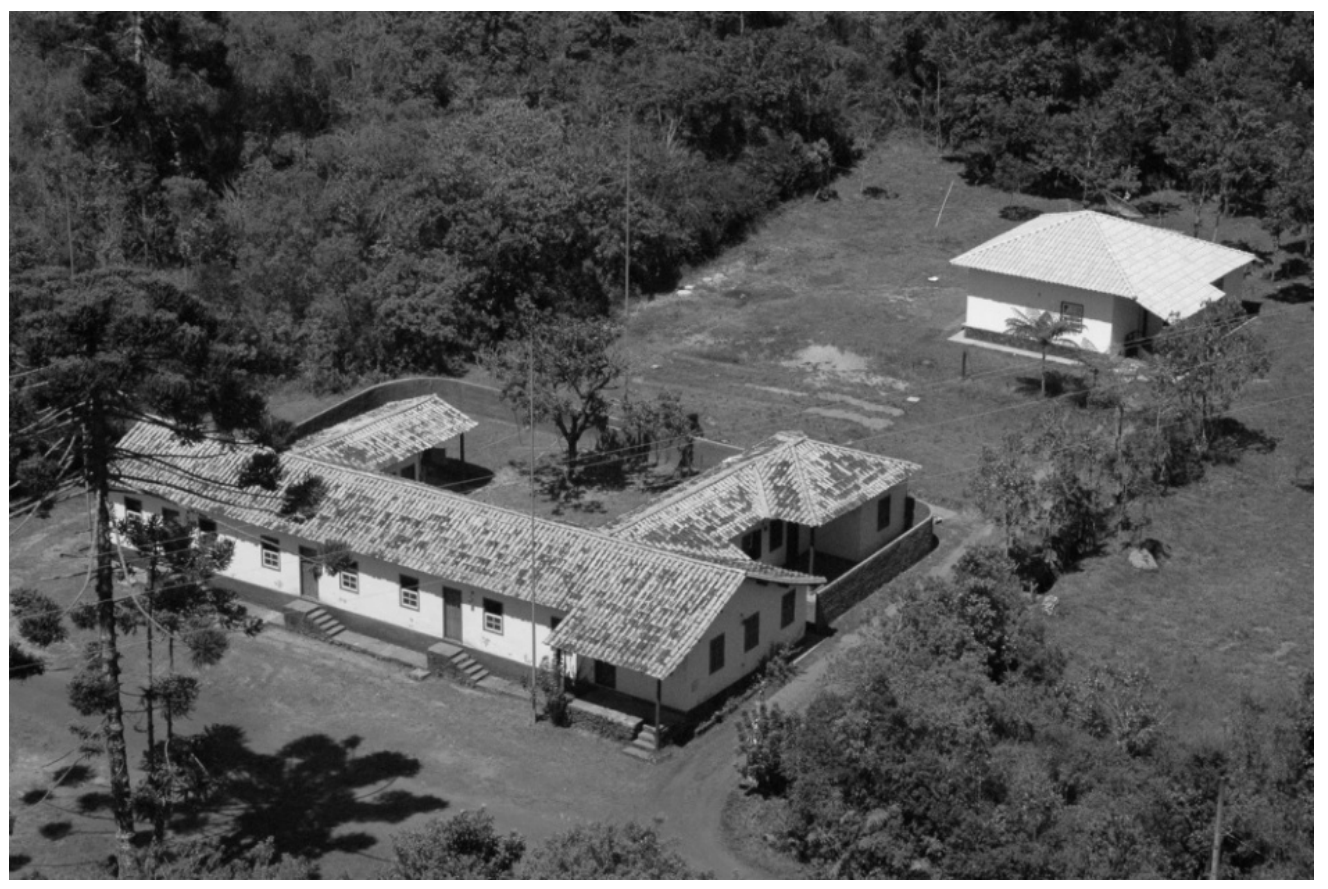

Figura 6: Vista aérea dos Alojamentos e Casa do Pesquisador. Fonte: IEF/PEIT (2007)

Casa Bandeirista: Considerado o primeiro edifício público da história de Minas Gerais (Figura 7), foi construída entre os anos de 1706 e 1708 e funcionava como posto fiscal para a cobrança dos quintos do ouro, vigilância e defesa do acesso às lavras de Ouro Preto. Atualmente abriga a exposição "Naturalistas", de caráter permanente, dedicada aos viajantes que percorreram e estudaram Minas Gerais. Segundo Bedim (2004), desde o início do século XIX o território do Itacolomi foi visitado e estudado por naturalistas, quando lá estiveram o botânico francês Auguste de Saint Hilaire, e os naturalistas Georg Wilhelm Freireyss, Friedrich Sellow, o alemão Johann Spix ${ }^{4}$ e Carl Friedrich Phillipp von Martius, dentre outros. Muitos deles registraram preciosos relatos que compõem uma rica literatura de viagens sobre a área. A literatura de viagens consiste em documentos textuais, relatos de exploradores ou pesquisadores que desbravaram determinada região em épocas remotas. Através desses registros, é possível resgatar alguns episódios interessantes da história da Serra do Itacolomi que permanecem desconhecidos do público em geral, com fins a estabelecer roteiros turísticos bem mais interessantes, informando aos visitantes a verdadeira e secular descrição dos caminhos, vilas e culturas (BEDIM, 2004). 


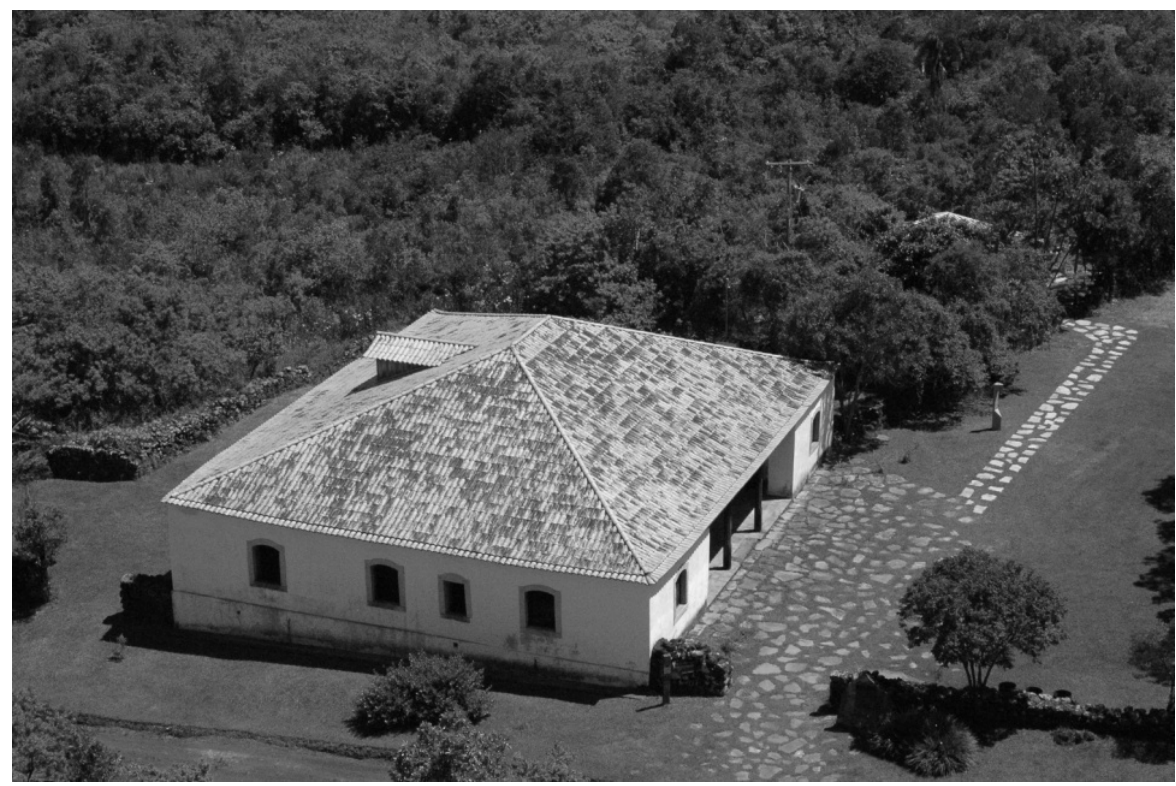

Figura 7: Vista aérea da Casa Bandeirista. Fonte: PEIT (2007).

Museu do Chá: No local funcionava a antiga fábrica de chá Edelweiss. (Figura 8). 0 maquinário utilizado na fábrica foi trazido da Alemanha. Além de parte do antigo maquinário, há no local uma exposição de fotos da fábrica quando em funcionamento. $O$ museu conta com um monitor permanente. Está inserido nas zonas de uso intensivo e histórico-cultural do parque.

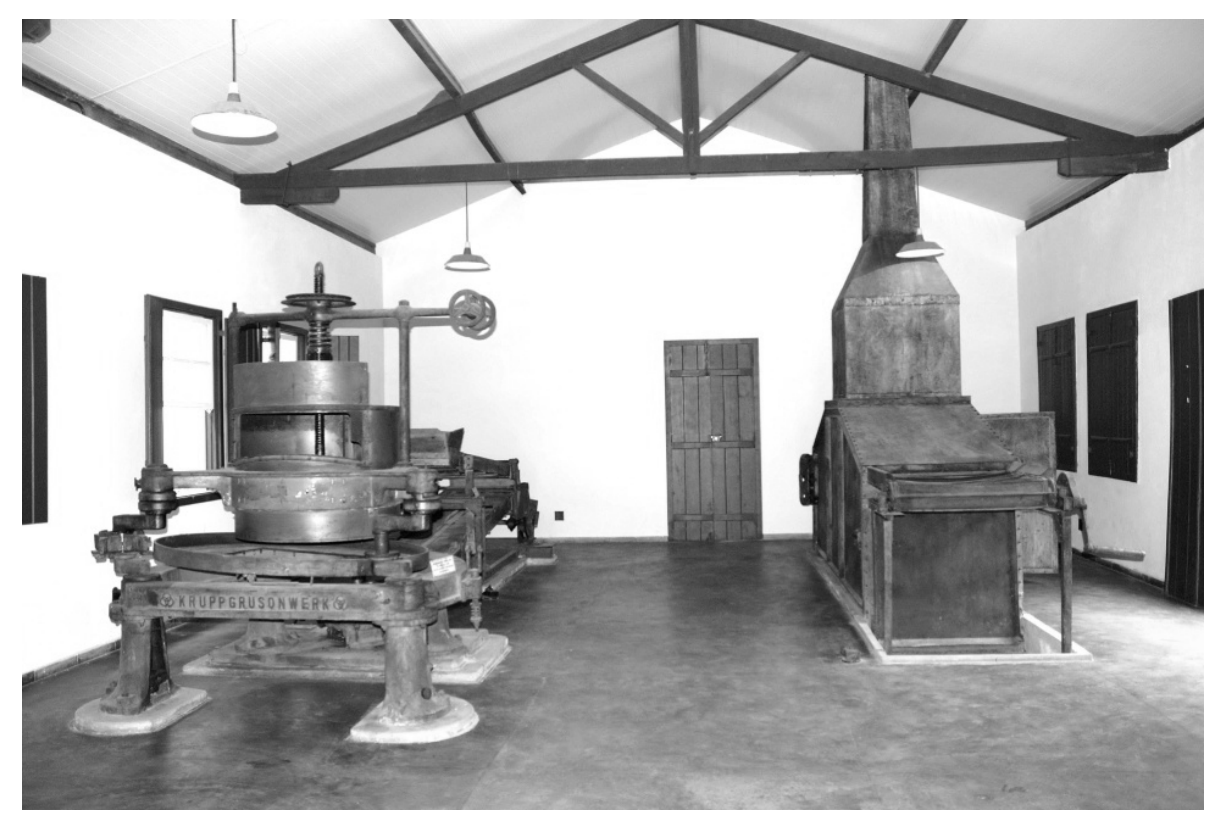

Figura 8: Parte interna do Museu do Chá. Fonte: PEIT (2007). 
Tirolesa: Situada na Lagoa da Capela, feita de eucalipto tratado e cabo de aço, utiliza-se de equipamentos característicos da escalada como mosquetão, fita tubular, cadeirinha, etc. Sua descida é acentuada e a parada final se dá dentro da própria lagoa. É operada, necessariamente, por dois monitores do PEIT. $O$ ingresso referente à tirolesa é pago no centro de visitantes, antes ou após sua utilização ao custo de $R \$ 5,00$. A tirolesa está inserida na zona de uso intensivo do PEIT (Figura 9),

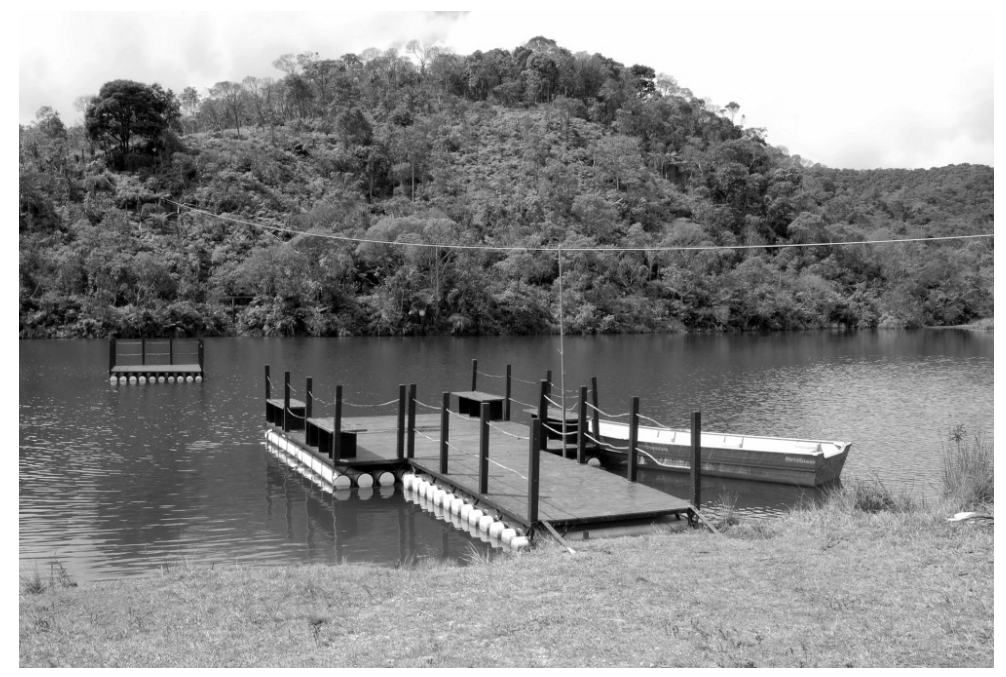

Figura 9: Tirolesa. Fonte: PEIT (2007).

Capela São José: Construída na primeira metade do século XX, sem datação precisa. A construção hoje existente não é mais a original, destruída por incêndio e esquecida durante muito tempo. Não é disponibilizado, pela gerência, um monitor para a Capela(Figura 10). A Capela São José está inserida na zona histórico-cultural, de acordo com o Plano de Manejo do PEIT (2007).

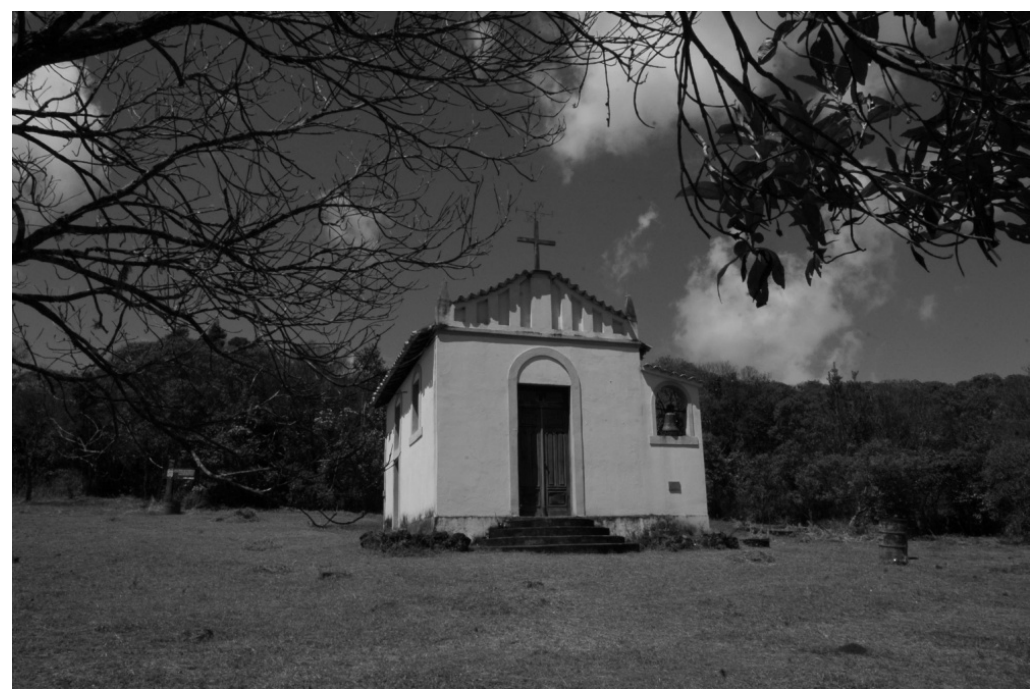

Figura 10: Capela São José. Fonte: PEIT (2007). 
Trilhas interpretativas: O Parque Estadual do Itacolomi conta com três trilhas interpretativas: Trilha do Forno, Trilha da Capela, Trilha da Lagoa (Figura 11); e uma expedição (Expedição ao Pico do Itacolomi). $\mathrm{O}$ ingresso referente às trilhas são pagos no centro de visitantes, antes ou após o percurso. O passeio ao Pico do Itacolomi custa $R \$ 10,00$ e as demais trilhas $R \$ 6,00$ por pessoa.

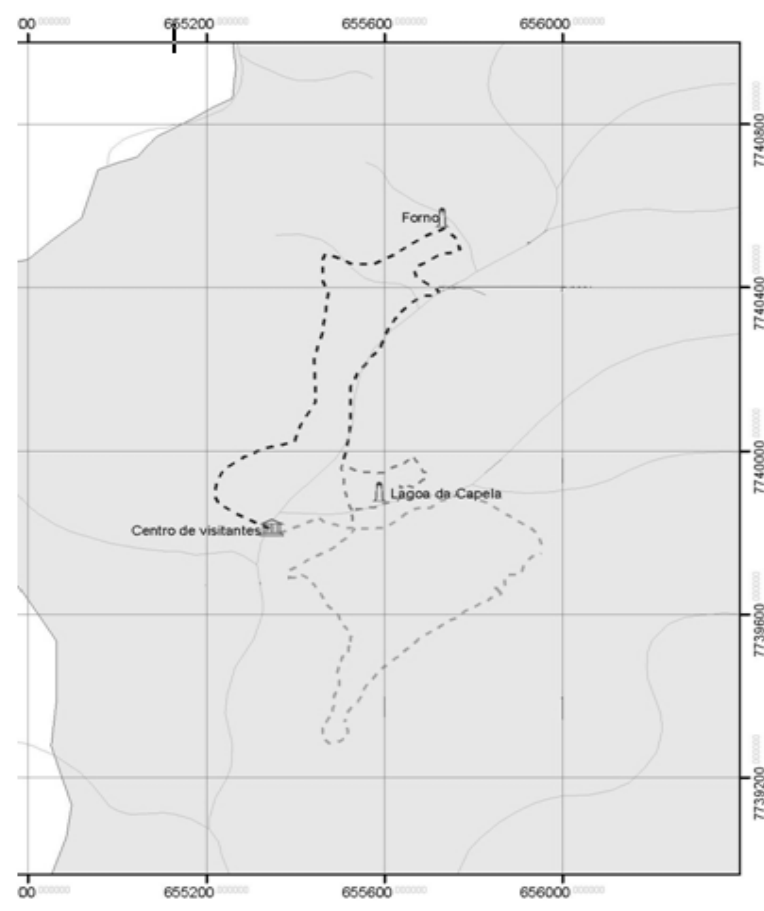

Trilhas Interpretativas da Fazenda do Manso

Legenda
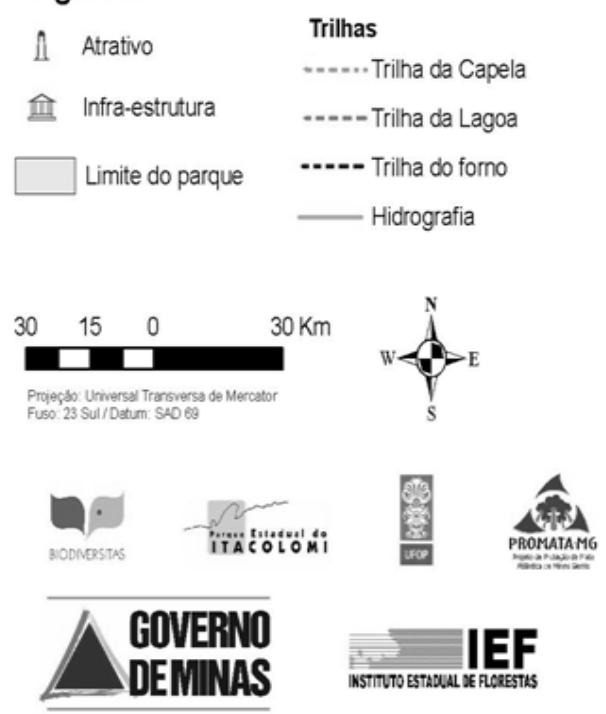

Figura11: Trilhas do Parque Estadual do Itacolomi. Fonte: Plano de Manejo do PEIT, Encarte 2 Planejamento e manual de gestão, Belo Horizonte, IEF, Outubro de 2007.

Na Trilha do Forno, o tempo aproximado de percurso é de 1 hora; esta trilha tem como tema "A sucessão ecológica e a importância das águas para a diversidade dos ambientes". A trilha do Forno possui cerca de 1200 metros de extensão e abriga as ruínas de um grande forno de cerâmica. Segundo Bedim (2004, p.6), nesta trilha há ruínas atribuídas à antiga Olaria Roque Pinto, as quais compõem um interessante sítio arqueológico, de onde acredita-se ter saído as primeiras peças de cerâmica (telhas, tijolos, etc.) utilizadas na edificação de Vila Rica, no período colonial. Ademais, a área já foi ocupada, no século XX, por grandes empresas de mineração, bem como serviu de extração madeireira para a produção de carvão vegetal (BEDIM, 2004). Ao longo do percurso pode-se visualizar pequenos cursos d'água, algumas regiões alagadiças, escadas, passarelas, bancos de madeira e placas informativas sobre a fauna e a flora. Essa trilha pode ser feita com acompanhamento de monitor ou não. Está inserida na zona de uso extensivo do PEIT.

Já a Trilha da Capela tem, aproximadamente, 1.400 metros de percurso, com duração, também aproximada, de 1 hora e seu tema é "A mata se recupera da ação do homem." A trilha tem início ao lado da Capela São José e percorre uma área em recuperação ecológica o que permite, aos visitantes, o contato direto com o processo de regeneração natural. Possui placas informativas sobre a temática proposta. Essa trilha pode ser 
feita com acompanhamento de monitor ou não. Está inserida na zona de uso extensivo do PEIT.

Por sua vez, a Trilha da Lagoa possui 450 m de extensão, cujo tempo aproximado de percurso é de 40 minutos. Seu tema é a "Diversidade de sistemas e de paisagens'. Circunda a área da Lagoa da Capela e é destinada, principalmente, ao público infantil. A trilha não possui placas informativas, mas possui passarelas e escadas em eucalipto tratado. Essa trilha pode ser feita com acompanhamento de monitor ou não. Está inserida na zona de uso extensivo do PEIT.

Expedição ao Pico do Itacolomi: Com duração aproximada de 4 horas e $6 \mathrm{Km}$ de percurso, a expedição ao pico é sempre realizada na companhia de monitores pois a trilha é de difícil visualização. Não possui placas informativas ou qualquer tipo de intervenção para facilitar a passagem em trechos mais difíceis como barrancos e rochas. A trilha serpenteia quase que totalmente por campos rupestres e a paisagem é bem rochosa. Está inserida na zona de uso extensivo do PEIT.

O principal atrativo turístico natural é o Pico do Itacolomi, que possui $1.772 \mathrm{~m}$ de altitude e atrai a atenção devido à sua estrutura peculiar. Devem ser observados os impactos causados pela variedade de acessos clandestinos ao atrativo, assim como o vandalismo, a permanência de visitantes para acampamento e a criminalidade - haja vista a ocorrência de assaltos no trajeto.

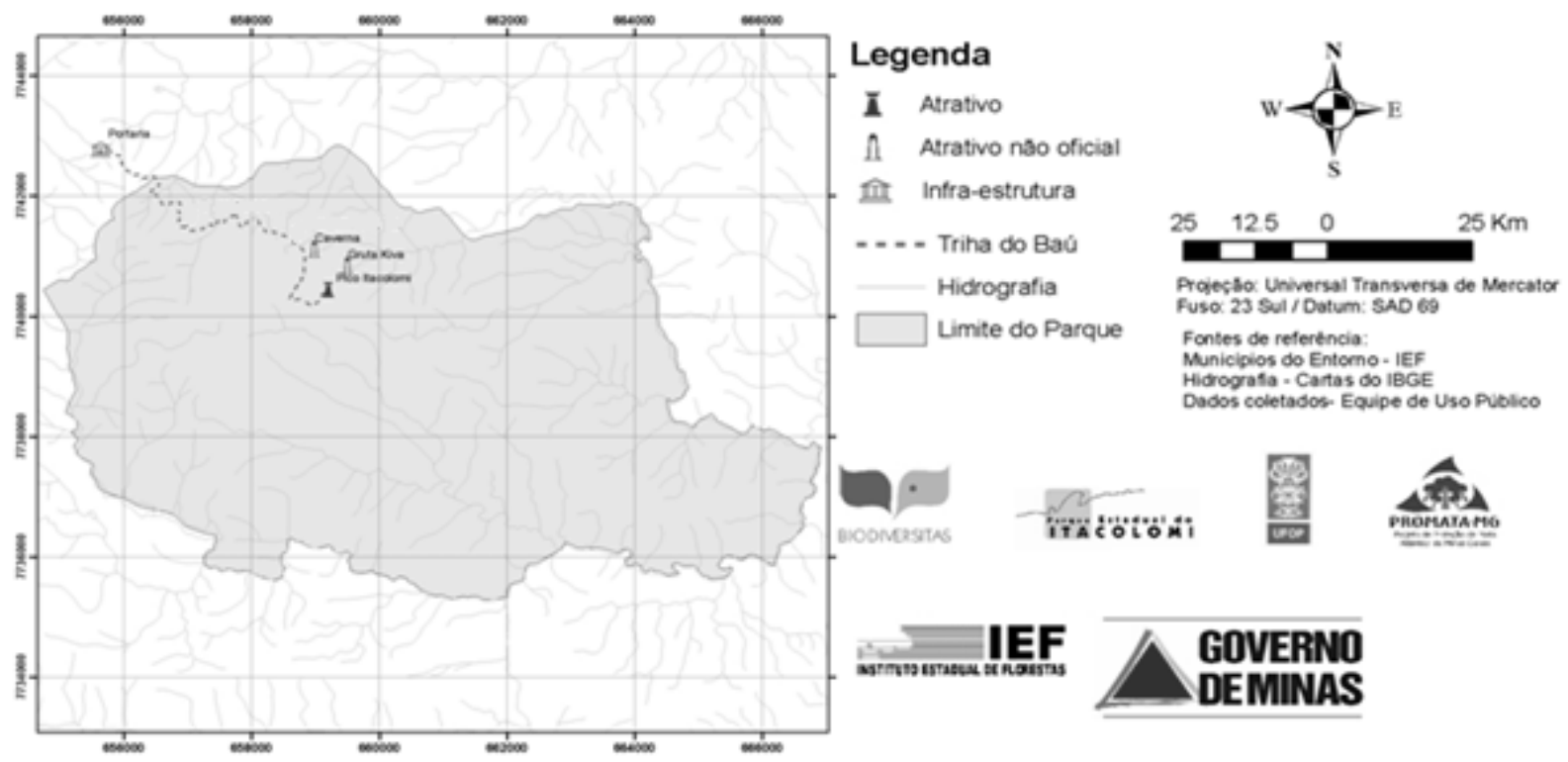

Pico do Itacolomi: referência em todos os tempos.

Figura 12: Mapa do principal percurso ao Pico do Itacolomi. Fonte: Plano de Manejo do PEIT, Encarte 2 Planejamento e manual de gestão. Belo Horizonte: IEF, Outubro de 2007. 
É valido destacar, ademais, dois roteiros alternativos que são percorridos pelos visitantes a partir de duas estradas vicinais que cortam o parque: a estrada para o mirante do Morro do Cachorro e a estrada para a represa do Custódio, situada no distrito de Lavras Novas.

O Mirante natural do Morro do Cachorro situa-se no alto de uma escarpa, de onde pode-se observar as cidades de Ouro Preto e Mariana. O acesso aos atrativos deste topo é realizado por estrada, porém no local não se encontra uma infraestrutura mínima de estacionamento, guarda-corpo ou rotatória para o veículo.

A Represa do Custódio possui $8 \mathrm{~km}$ de extensão, com remanescentes de mata nativa e um trecho de reflorestamento de eucaliptos. Diversas atividades poderiam ser desenvolvidas no local, porém isto não ocorre. A Represa do Custódio é limítrofe ao parque e sofre com visitações clandestinas que, por não ter aporte referente à presença de salva-vidas, ocasiona vez ou outra a morte de alguns desses visitantes.

\section{Análise de dados sobre a visitação e uso dos atrativos do PEIT.}

Ao analisar comparativamente os dados relativos aos 4 primeiros meses de funcionamento do Programa de visitação do Itacolomi, Bedim (2004, p.9) observa que o Protur-Peit recebeu 3.250 visitantes entre maio e agosto de 2004, conforme a tabela 1:

Tabela1: Dados comparativos do fluxo de visitantes do PEIT em 2004. Fonte: Bedim (2004, p.9).

\begin{tabular}{|c|c|c|c|c|}
\hline MÊS & Veículos & Trilhas & Visitantes & Arrecadação(R\$) \\
\hline Maio & 89 & 146 & 756 & $3.124,50$ \\
\hline Junho & 105 & 264 & 1351 & $4.907,00$ \\
\hline Julho & 94 & 216 & 675 & $3.308,50$ \\
\hline Agosto & 41 & 210 & 468 & $2.212,00$ \\
\hline TOTAL & 329 & 836 & 3250 & $13.552,00$ \\
\hline
\end{tabular}

De acordo com Bedim (2004, p.9), o considerável fluxo de visitantes em maio e junho de 2004 foi reflexo da maciça divulgação veiculada em emissoras de rádio e televisão quando da reabertura do parque. Nota-se, a partir de junho, um gradativo decréscimo do número de visitantes. A queda percebida no mês de agosto provavelmente sofre influência do fim do período das férias escolares de julho, bem como do término dos Festivais de Inverno e do Fórum das Artes, eventos que atraem grande número de turistas para as cidades de Ouro Preto e Mariana (BEDIM, 2004, p.9).

Em 2005, de acordo com a gerência do parque, houve 3341 visitantes (entre pagantes e não pagantes) com um total de 398 trilhas que abrangem também a expe- 
dição ao Pico do Itacolomi e uma arrecadação de $\mathrm{R} \$ 11.197,00 .^{5}$

No ano de 2006, o número de visitantes permaneceu relativamente estável, porém é perceptível um discreto decréscimo na arrecadação: foram 3154 visitantes, 316 trilhas e uma arrecadação total de $\mathrm{R} \$ 9.869,00$.

Este cenário de estagnação tanto da arrecadação quanto do fluxo de visitantes é diagnosticado também no ano seguinte, em 2007, totalizando 3299 visitantes, 218 trilhas e 79 tirolesas - com uma arrecadação de $R \$ 658,00$ com trilhas, $R \$ 352,00$ com a tirolesa e arrecadação total de $\mathrm{R} \$ 9.732,00$.

Em 2008, houve um acréscimo substancial dos índices de visitação e da arrecadação, contabilizando um total de 7769 visitantes, 647 trilhas, 201 tirolesas e 103 dias alugados de uso do camping e 9 aluguéis de churrasqueira - somando uma arrecadação total de $\mathrm{R} \$ 31.681,90$.

Em 2009, até julho foram 5553 visitantes, 505 trilhas, 278 tirolesas, 16 aluguéis de churrasqueira e 170 dias alugados de uso do camping.

O Gráfico 1 ilustra o número de visitantes e a arrecadação ao longo dos anos.

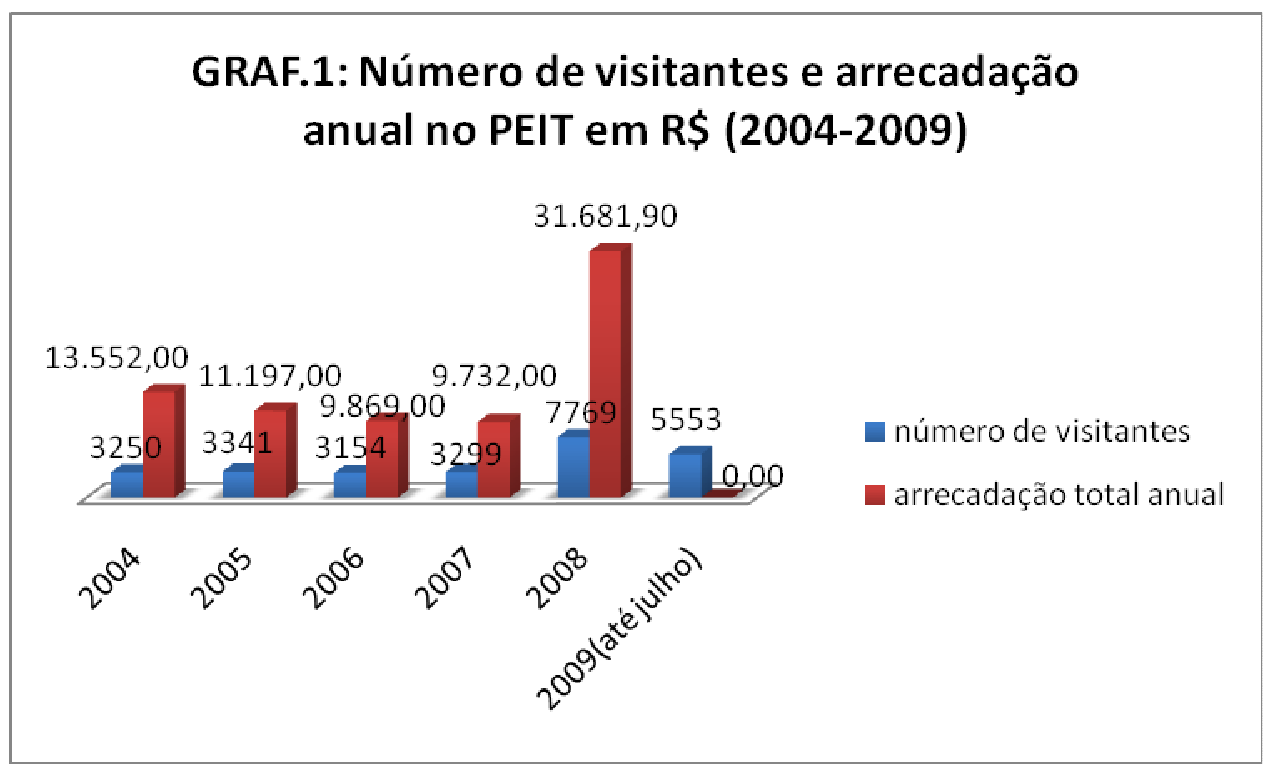

Fonte: Dados de campo coletados junto ao IEF (jan.2010). Nota sobre a correção monetária dos preços apresentados: De acordo com o site cálculos.com, o ano de 2009 possuía até 12/09 a UFIR de 1,9372 real. Embora a UFIR - Unidade Fiscal de Referência - tenha sido extinta em 2000 para fins fiscais, entendemos que a mesma é um parâmetro de valores monetários.

Constatamos que até 2007 havia um programa realizado pelo parque onde o morador pagava apenas $R \$ 1,00$ de entrada e possuía transporte da portaria até o centro de visitantes. Ainda em 2007 foi implantado mais um atrativo turístico construí- 
IEquipamentos turísticos do Parque Estadual do Itacolomi (MG): análise das instalações e dos atrativos construídos

do, a tirolesa, que se consolidou como opção de lazer dentro do parque.

Em 2008 a coordenação passa a contabilizar dados de uso do camping e da churrasqueira; os moradores locais passam a pagar $\mathrm{R} \$ 3,00$ de entrada e o transporte interno de visitantes é cortado pela direção do parque.

Comparando tais números com os dados de anos anteriores, em 2008 e 2009 percebemos um grande aumento da visitação e receita do parque, o que pode ser atribuído a dois fatores principais: i) As inaugurações dos atrativos construídos a partir de 2008, como tirolesa, parque infantil, etc., além da liberação da lagoa para nado; ii) Inauguração da exposição permanente na casa bandeirista. O gráfico 2 ilustra o total de equipamentos e atrativos utilizados por ano.

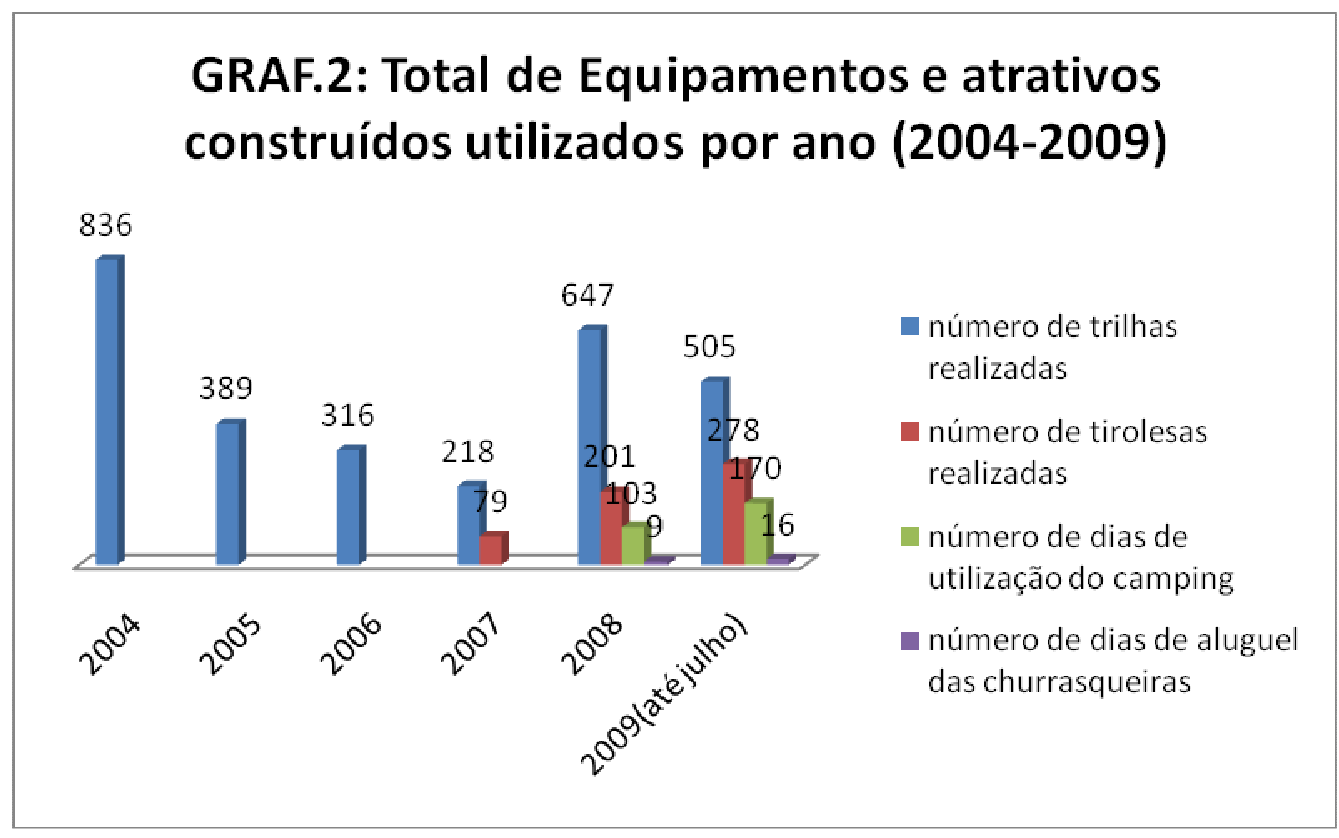

Fonte: Dados de campo coletados junto ao IEF (jan.2010).

\section{A estrutura informacional do PEIT}

A estrutura informacional é imprescindível no ambiente dos parques, pois através da mesma se é passada ao visitante a missão institucional do parque, o modo como ela é desenvolvida, as normas de conduta vigentes naquele ambiente, informações relevantes da unidade de conservação (atrativos naturais, construídos, fauna, flora e equipamentos presentes) e também, a sinalização para fácil locomoção e exploração das áreas abertas ao público da unidade. 
A estrutura informacional do Parque Estadual do Itacolomi compreende a portaria do parque acrescido do centro de informações, centro de visitantes, placas de sinalização e informativas sobre determinado tema e a presença de monitores em pontos estratégicos e no acompanhamento nas trilhas.

\section{Análise das formas de estímulo à visitação do PEIT}

De acordo com o resumo executivo do plano de manejo do Parque Estadual do Itacolomi, a missão do parque, além de salvaguardar os atributos físico-bióticos de seu território, é proteger os patrimônios naturais e histórico-culturais, patrimônioscenários da ocupação de Minas Gerais, referenciado pelo Pico do Itacolomi, integrando as comunidades e as Unidades de Conservação da região ${ }^{6}$.

A citada missão de alcançar a integração das comunidades passa, dentre outras ações, por uma divulgação direcionada e adequada do próprio parque a seu entorno e demais regiões.

Através de pesquisa realizada com o material disponível no parque, constatouse que até meados de 2009 o Plano de Divulgação do parque e seus eventos era realizado por uma empresa contratada (não identificada), especificamente, para essa função, porém houve o rompimento com esta empresa por motivos não identificados, o que resultou no bloqueio do Plano de Divulgação traçado até então.

A assessoria de comunicação do IEF (ASCOM) tornou-se responsável, desde meados de 2009, por todo o serviço de comunicação do parque.

Constatou-se que houve um detrimento do setor de divulgação e marketing do parque, o que resultou na execução de divulgações pontuais que contemplam apenas alguns dos eventos realizados na unidade. Os veículos de comunicação utilizados para estas divulgações pontuais são: rádio, jornal, televisão e panfletos.

Não houve uma renovação nos panfletos distribuídos no parque e entorno e o único link oficial do parque encontra-se em www.parquesdeminas.mg.gov.br e apresenta informações incorretas como endereço de e-mail do parque e telefone para contato.

A avaliação que se faz é que com a desvinculação da empresa contratada e a não contratação de outra especializada no setor o Parque Estadual do Itacolomi perdeu muito na divulgação de seus atrativos construídos e naturais, o que culmina numa menor divulgação da imagem do parque ante a sociedade e a diminuição do fluxo de visitantes nos atrativos. 


\section{A Análise SWOT dos atrativos construídos}

Após a descrição dos atrativos construídos e do panorama de funcionamento em diferentes áreas do Parque Estadual do Itacolomi, daremos início a uma análise dos equipamentos turísticos, dentro da concepção de análise $\mathrm{SWOT}^{7}$. De acordo com Kotler e Kevin (2006), a análise SWOT é uma ferramenta utilizada para fazer análise de cenário (ou análise de ambiente), sendo usado como base para gestão e planejamento estratégico de uma corporação ou empresa, podendo também ser aplicável na análise de destinos turísticos.

Segundo Kotler e Kevin (2006), trata-se de uma avaliação global da forças, fraquezas, oportunidades e ameaças, permitindo sistematizar todas as informações disponíveis e obter uma leitura categorizada do objeto de estudo. A proposta de análise de ambiente do método SWOT é convenientemente representada na Figura 13:

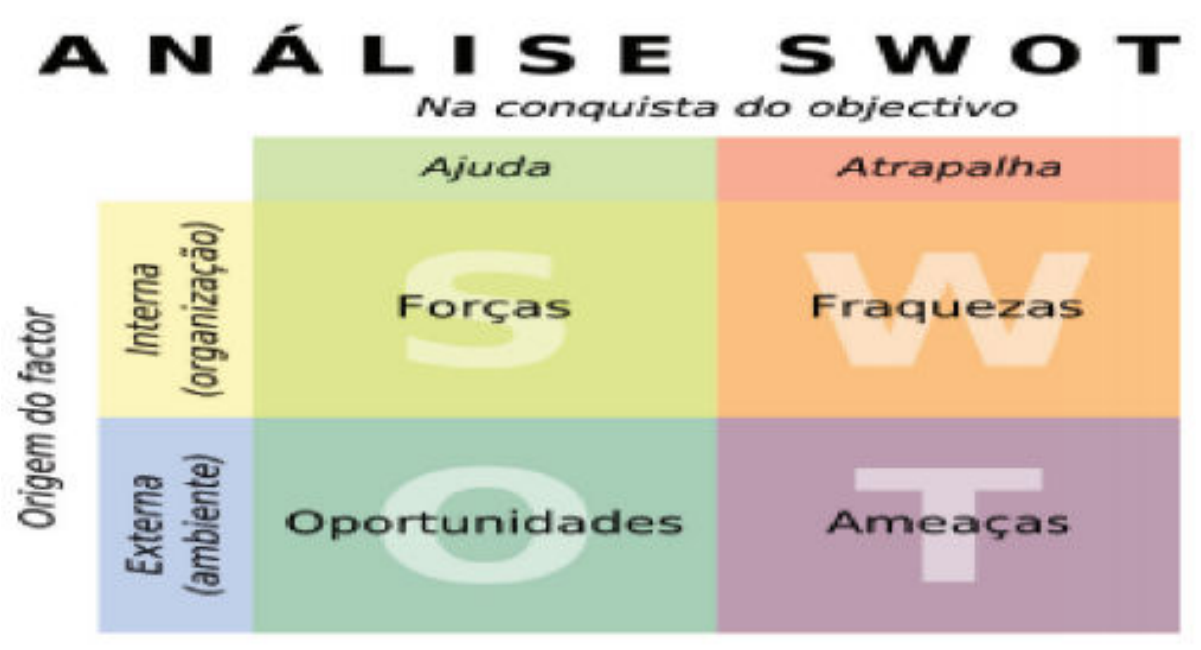

Figura 13: Quadro Análise SWOT ${ }^{8}$.

Esta análise de cenário se divide em ambiente interno (Forças e Fraquezas) e ambiente externo (Oportunidades e Ameaças). Sua importância no apoio à formulação de estratégias deriva de sua capacidade de promover um confronto entre as variáveis externas e internas, facilitando a geração de alternativas de escolhas estratégicas, bem como de possíveis linhas de ação ${ }^{9}$. O ambiente interno é o resultado de estratégias de atuação definidas pela própria corporação ou empresa e pode ser controlado pelos dirigentes da organização, diferentemente do ambiente externo. Não podemos controlá-lo, mas devemos monitorá-lo. 
Bedim, B.P., Campos, C.F.; Vidal, T.C.

Quadro 1 - Análise SWOT da gestão da visitação pública no Parque Estadual do Itacolomi, com enfoque na utilização dos equipamentos e atrativos construídos.

\begin{tabular}{|c|c|c|c|}
\hline Forças & Fraquezas & Oportunidades & Ameaças \\
\hline $\begin{array}{l}\text { Equipamentos e atrativos } \\
\text { geograficamente concen- } \\
\text { trados na área da Fazenda } \\
\text { do Manso }\end{array}$ & $\begin{array}{l}\text { Deficiência na comu- } \\
\text { nicação interna dos } \\
\text { agentes que operam } \\
\text { a visitação } \\
\text { Site oficial do parque } \\
\text { deficiente }\end{array}$ & $\begin{array}{l}\text { Atrativos e equipamentos } \\
\text { que contemplam diferentes } \\
\text { segmentos de público }\end{array}$ & $\begin{array}{l}\text { A gestão do programa de } \\
\text { visitação do parque é } \\
\text { dependente de recursos } \\
\text { externos oriundos de } \\
\text { compensações ambien- } \\
\text { tais das grandes empre- } \\
\text { sas de minério de ferro } \\
\text { da região }\end{array}$ \\
\hline $\begin{array}{l}\text { Diversificação da oferta } \\
\text { turística, o que permite a- } \\
\text { trair e atender diferentes } \\
\text { perfis de demanda, haja } \\
\text { vista os equipamentos dis- } \\
\text { poníveis }\end{array}$ & $\begin{array}{l}\text { Divulgação da ima- } \\
\text { gem do parque é defi- } \\
\text { ciente }\end{array}$ & $\begin{array}{l}\text { Cidades do entorno foca- } \\
\text { das no turismo histórico- } \\
\text { cultural, carecendo de al- } \\
\text { ternativas para a prática de } \\
\text { turismo em áreas naturais, } \\
\text { o que reforça a importância } \\
\text { do PEIT neste segmento }\end{array}$ & $\begin{array}{l}\text { Sazonalidade turística } \\
\text { (dificulta planejamento de } \\
\text { monitores) }\end{array}$ \\
\hline $\begin{array}{l}\text { A portaria do Parque locali- } \\
\text { za-se às margens da BR- } \\
356\end{array}$ & $\begin{array}{l}\text { Falta de planejamen- } \\
\text { to, sinalização e mo- } \\
\text { nitoramento da utiliza- } \\
\text { ção dos atrativos } \\
\text { construídos }\end{array}$ & $\begin{array}{l}\text { Necessidade de maior } \\
\text { divulgação da imagem do } \\
\text { Parque nas cidades da } \\
\text { região }\end{array}$ & $\begin{array}{l}\text { Questões sociais: } \\
\text { Ressentimento de parte } \\
\text { da população pela supos- } \\
\text { ta "restrição" a entrada no } \\
\text { parque }^{10}\end{array}$ \\
\hline $\begin{array}{l}\text { Instalações turísticas recen- } \\
\text { tes, em bom estado de con- } \\
\text { servação }\end{array}$ & $\begin{array}{l}\text { Gerência do PEIT não } \\
\text { capacitada para a } \\
\text { gestão do turismo }\end{array}$ & $\begin{array}{l}\text { Desenvolvimento de pro- } \\
\text { dutos específicos para } \\
\text { atender ao público da Co- } \\
\text { pa do Mundo de } 2014\end{array}$ & $\begin{array}{l}\text { Falta diálogo entre a ges- } \\
\text { tão do parque e os pro- } \\
\text { gramas governamentais } \\
\text { de apoio ao turismo em } \\
\text { Ouro Preto }\end{array}$ \\
\hline $\begin{array}{l}\text { Localização estratégica do } \\
\text { Parque em relação a pólos } \\
\text { emissores (Belo Horizonte), } \\
\text { e pólos receptores (Ouro } \\
\text { Preto, Mariana, etc). }\end{array}$ & $\begin{array}{l}\text { Ausência de transpor- } \\
\text { tes da portaria do } \\
\text { parque até os equipa- } \\
\text { mentos e atrativos }\end{array}$ & $\begin{array}{l}\text { Possibilidade de utilização } \\
\text { dos equipamentos do par- } \\
\text { que para a educação ambi- } \\
\text { ental }\end{array}$ & $\begin{array}{l}\text { Falta de divulgação dos } \\
\text { produtos e serviços do } \\
\text { Parque nas cidades da } \\
\text { região }\end{array}$ \\
\hline
\end{tabular}

Fonte: Dados primários da pesquisa, 2010.

Após adquirir ciência das limitações e pontos positivos do conjunto de atrativos construídos do PEIT e de seu entorno influenciador, é necessário analisar as oportunidades e as forças, bem como contrastar fragilidades e as ameaças para buscarmos estratégias que minimizem e monitorem os aspectos negativos e maximizem as potencialidades. Analisaremos cada ponto da tabela acima, para então cruzarmos os dados. 


\section{Fragilidades}

Deficiência na comunicação interna. Não existe um procedimento eficaz de comunicação entre os setores e a portaria, ou entre o credenciamento e a coordenação do PEIT. Isto ocasiona brechas no sistema receptivo, pois muitas vezes o credenciamento direciona turistas para os atrativos construídos sem que a coordenação fique sabendo, impossibilitando assim o encaminhamento de monitores para dar o suporte ao visitante no atrativo.

Esta brecha de comunicação é formada por um somatório de fatores observados in loco. São estes:

Falta de rádios de comunicação em quantidade e em estado ideal de uso (sempre carregado e vistoriado) entre credenciamento e coordenação.

Falta de rádios de comunicação entre coordenação e monitores.

Falta de organização do setor de coordenação em agendar visitas e hospedagens e repassar os dados para a coordenação.

Divulgação deficiente dos produtos e serviços: Os atrativos construídos sofrem com a falta de divulgação dos mesmos, o que ocasiona um uso bem abaixo do potencial de utilização disponível. Esta ociosidade da oferta é reflexo da sazonalidade da demanda.

Falta de planejamento para otimizar a utilização dos atrativos construídos: Alguns atrativos como o parque infantil de madeira e a lagoa da tirolesa não possuem um efetivo planejamento de utilização, uma vez que foi observada a falta de limite de idade para utilização do parque (o que pode ter ocasionado um acidente com um homem embriagado) e a ausência de salva-vidas ou profissionais especializados na área da lagoa da tirolesa (verificou-se, in loco, relatos dos monitores de quase-afogamentos de visitantes de diversas idades enquanto nadavam na lagoa).

Falta de sinalização nos equipamentos e atrativos: A política do parque proíbe que visitantes estacionem seus carros em frente aos atrativos e equipamentos em geral, porém não há nenhum tipo de sinalização em frente aos atrativos que indique esta proibição, o que ocasiona inúmeros carros estacionados irregularmente.

Falta de monitoramento dos equipamentos: Os atrativos não são sempre monitorados durante o tempo em que os turistas os estão usufruindo, o que ocasiona má utilização de alguns equipamentos e atrativos.

Ausência de transportes da portaria até os atrativos e equipamentos. A portaria e o setor de credenciamento do parque ficam a aproximadamente seis quilômetros do setor receptivo e dos atrativos histórico-culturais, e isto restringe em grande parte o acesso, além de segregar - mesmo que involuntariamente - determinados segmentos socioeconômicos. 
Bedim, B.P., Campos, C.F.; Vidal, T.C.

\section{Oportunidades para o turismo no PEIT:}

Atrativos que contemplam diferentes segmentos de público: Os atrativos construídos contemplam diferentes segmentos de público visitante, uma vez que existam atrativos voltados para o ecoturismo, o turismo pedagógico (desenvolvido para aprendizagem escolar), além de turismo histórico e de recreação.

Proximidade do parque em relação à BR-356: A portaria do parque fica às margens da BR-356, o que facilita o acesso aos atrativos, ao contrário de outras UC's que precisam ser acessadas por estradas secundárias e de baixa manutenção.

Proximidade do PEIT com pólos emissores (Belo Horizonte) e pólos receptores (Ouro Preto e Mariana). A portaria do parque é limítrofe à zona urbana da cidade de Ouro Preto e está localizada a $101 \mathrm{~km}$ da capital mineira Belo Horizonte, e a 14 km de Mariana. Há ainda a oportunidade de se abrir uma portaria bem próxima à cidade de Mariana. Esta proximidade com a capital mineira e especialmente com dois importantes pólos receptores facilitam a divulgação e captação de turistas para visitarem o parque e seus atrativos.

Desenvolvimento de produtos específicos para atender ao público da Copa do Mundo de 2014. A capital Belo Horizonte será uma das cidades-sede deste grande evento esportivo, e o Itacolomi é o parque com melhor infraestrutura turística de Minas Gerais. Ademais, as cidades do entorno do Parque estão focadas no turismo históricocultural, carecendo de alternativas para a prática do turismo em áreas naturais.

Políticas públicas nacionais de turismo que abrangem Ouro Preto. O município de Ouro Preto é participante de programas governamentais voltados para o Turismo, como o Programa Destinos Indutores (Ministério do Turismo), o Programa de Aceleração do Crescimento Cidades Históricas (PAC Cidades Históricas) que junto com o Programa BID/Monumenta propicia melhorias que beneficiarão, entre outros segmentos, o turismo no município.

Potencialidade para projetos de Extensão Universitária e Pesquisa Científica. O campus principal da Universidade Federal de Ouro Preto (UFOP) localiza-se bem próximo ao parque, com cursos de Turismo, Biologia, Geologia, Engenharia Ambiental, Economia, Museologia etc. A universidade e especificamente os cursos citados podem contribuir grandemente para o aprimoramento dos atrativos construídos do PEIT, seja através de projetos, estudos ou agregação de informações e práticas nestes equipamentos.

\section{Forças do Turismo (No PEIT e entorno):}

Localização geográfica dos atrativos do PEIT: Apesar de ficar a aproximadamente seis quilômetros da portaria, os atrativos construídos se concentram na área de maior infraestrutura do parque, o que facilita a visitação destes atrativos e proporciona maior conforto para o visitante, abrindo assim o leque de segmentos interessados na visitação. 
Hospital próximo à portaria do PEIT. O hospital próximo a portaria do PEIT ajuda a compor indiretamente a infraestrutura de apoio para a utilização dos atrativos.

Ecoturismo. Os atrativos construídos no PEIT e o desafio de sua gestão para a utilização de forma sustentável do patrimônio natural e histórico-cultural do parque, vão de encontro à forma de turismo normalmente praticada pelos ecoturistas.

Possibilidade de utilização destes atrativos para a educação ambiental. Alguns destes atrativos construídos são utilizados para a educação ambiental de jovens e adolescentes, porém a natureza dos atrativos permite que todos sejam utilizados para a educação ambiental.

Equipamentos de alimentação. Dentro do PEIT e próximo à portaria, encontram-se diferentes opções de equipamentos de alimentação, que ajudam a compor a macroestrutura do parque ${ }^{11}$.

Ecossistema diversificado. A presença de um ecossistema diversificado no parque e região constitui um diferencial ou agregador de valor para a escolha da visitação da região.

Atrativos naturais. A presença de inúmeros atrativos naturais e construídos no parque pode servir para potencializar a visitação ao PEIT.

Infraestrutura básica em bom estado de conservação. A infraestrutura do parque em bom estado de conservação estimula a permanência e o retorno do turista.

\section{Ameaças que podem afetar o turismo e os equipamentos da UC:}

Serão discutidos, neste item, os fatores que desfavorecem o Parque Estadual do Itacolomi na escolha de destino a ser visitado pelo turista.

Falta de divulgação dos produtos e servicos do Parque nas cidades da região. Esta carência na divulgação ocasiona um índice de visitação aquém do possível ante a proximidade dos pólos emissores Ouro Preto e Mariana.

Dependência de recursos oriundos de compensações ambientais de grandes empresas mineradoras regionais, o que é indicativo da não sustentação financeira do projeto de turismo do parque.

Site oficial do parque deficiente. A falta de atualização de meios de contato (telefones errados) e outras informações sobre o parque dificulta a visitação a Unidade de Conservação em questão.

Sazonalidade da demanda. A sazonalidade da demanda de visitantes existente no PEIT dificulta a criação de um quadro fixo de funcionários voltados para o atendimento do público, uma vez que a mão-de-obra necessária em épocas de pico de visitação (como julho) é bem superior às épocas de baixa temporada. Isso ocasiona um déficit de pessoal e superávit em épocas distintas, que não podem ser solucionadas facilmente. 
Questões sociais: Ressentimento de parte da população pela suposta "restrição" à entrada no parque. Uma parcela da população por diferentes motivos é contrária ao parque e seus ideais e normas. Isto ocasiona uma propaganda negativa repercutida nos pólos turísticos de Ouro Preto e Mariana uma vez que, muitos dos descontentes trabalham em atividades de contato direto com o turista nestas duas localidades.

Gestores do PEIT não capacitados para o turismo. Foi constatado, nas análises in loco, uma ausência de profissionais capacitados em gerência e planejamento de recursos humanos e gerência e planejamento de equipamentos turísticos, sendo que os equipamentos presentes no parque são geridos de forma amadora e desprovidos de análises e planejamentos específicos.

\section{Propostas para o manejo dos atrativos construídos do PEIT}

Após a descrição de cada item auferido, devemos cruzar os dados de Forças $x$ Oportunidades e Ameaças x Fragilidades para obtermos assim uma visão preliminar a respeito das linhas estratégicas a serem adotadas que viabilizem a melhoria em diferentes campos dos atrativos construídos do PEIT.

\section{Forças e Oportunidades}

O parque possui uma posição geográfica estratégica em relação à demanda e à BR-356, haja vista a proximidade com as cidades de Ouro Preto e Mariana, e ainda, a localização em relação a consolidados pólos emissores de visitantes como a capital Belo Horizonte. A distribuição espacial dos atrativos construídos e dos equipamentos circunscritos ao parque também é favorável.

Destaca-se também a composição da oferta turística do parque, um somatório de diversidade de equipamentos, ecossistemas, atrativos naturais, boa infraestrutura do parque e suas adjacências junto com a possibilidade de utilização dos atrativos para a educação ambiental e a presença da Universidade Federal de Ouro Preto, além da política pró-turismo que envolve o município de Ouro Preto. Tais elementos compõem claramente o esboço de uma oferta turística sólida cujo uso poderia ser otimizado caso os gestores do PEIT considerassem esta combinação de fatores.

\section{Ameaças e Fragilidades}

Após a análise podemos perceber claramente que o parque possui deficiências no âmbito interno e externo.

Internamente, o problema de comunicação e planejamento/organização é visível em diversas esferas. Externamente, a falta e descuido com a divulgação da Unidade faz com que a demanda turística que visita as cidades de Ouro Preto e Mariana não se converta em demanda efetiva do parque. Há ainda as oscilações de fluxo relacionadas à sazonalidade na visitação. 
Sugestões de melhorias no âmbito interno do PEIT: É preciso uma revisão geral no modo de gestão até agora adotado, para a elaboração de um plano de ações que contemplem:

Uma reestruturação de equipamentos de comunicação e a criação de uma rede segura de comunicação (que esteja sempre em funcionamento) entre portaria, credenciamento, coordenação e monitores.

Planejamento eficiente de utilização dos equipamentos e atrativos construídos, estabelecendo idade mínima e máxima para sua utilização, deslocamento de um monitor para cada atrativo construído (para orientação ao visitante e monitoramento do atrativo), implantação de sinalização de "proibido estacionar" em frente aos atrativos e cursos de gerenciamento em recursos humanos para a equipe gestora do parque.

Criação de convênio de estágio com a Universidade Federal de Ouro Preto, estabelecendo assim um quadro de pessoal qualificado para o atendimento ao público, sendo que a contratação de estagiários deve corresponder às principais oscilações anuais do fluxo, auxiliando ainda na elaboração de atividades ligadas à educação ambiental nos atrativos.

Sugestões de melhorias no âmbito externo do PEIT

É necessária a designação ou contratação de uma equipe de profissionais de marketing para criar uma estratégia de divulgação adequada, levando em conta as peculiaridades que envolvem o parque e sua proximidade a dois pólos turísticos e à capital mineira; a reformulação do site oficial da Unidade e um trabalho de conscientização e melhoria da imagem do parque com a população do entorno.

\section{Proposta de roteiro de análise de equipamentos e atrativos turísticos construídos}

Durante a análise dos equipamentos e atrativos construídos do Parque Estadual do Itacolomi, ficou evidente a falta de modelos ou métodos de análise que possam ser aplicados para qualquer tipo de atrativo, observando suas peculiaridades, e que sejam capazes de produzir dados específicos sobre o atrativo em análise, compondo assim um escopo metodológico de planejamento aplicado.

Propomos então, com base na no método SWOT, um roteiro de análise de equipamentos e atrativos turísticos construídos que considera as peculiaridades de cada realidade, visando a gerar a base de estudos e planejamentos de ações, maximizando uso do atrativo ou equipamento, minimizando e monitorando os aspectos negativos. O roteiro compõe-se de 3 etapas principais: 
Levantamento e estudo turístico do entorno.

No intuito de auferir o raio de influência que o atrativo atinge, é preciso analisar os fluxos turísticos que convergem para a micro-região onde ele está inserido, considerando os pólos turísticos receptores adjacentes como possíveis alavancadores para a visitação do atrativo turístico.

Levantamento e estudo geográfico do entorno.

O levantamento geográfico do entorno traçará qual a infraestrutura básica (estradas, postos de emergência, transporte, etc.), além de demonstrar o relevo e acidentes geográficos a serem transpostos pelo turista, a partir do atrativo até aos itens de infraestrutura básica disponíveis.

Análise de utilização e desgaste do atrativo.

Realização de um estudo da forma de utilização do atrativo que vislumbre impactos ao meio no qual está inserido, riscos a segurança do turista, desgaste em decorrência de uso, levantamento da capacidade de carga, a necessidade de um monitor ou não no atrativo e formas de prestação de primeiros socorros e remoção hospitalar.

Os resultados da aplicação deste roteiro de análise podem servir de subsídio para o planejamento e desenvolvimento de ações nos campos: pedagógico, ambiental, de marketing, de recursos humanos, de gestão do atrativo e de segurança, dentre outros, e que tragam melhorias e minimização de negatividades.

\section{Considerações finais}

Após o estudo do Plano de Manejo do PEIT, coleta de dados na administração do parque, descrição dos atrativos construídos e observação "in loco" do funcionamento do Parque Estadual do Itacolomi, pode-se perceber que os equipamentos e atrativos construídos do parque estão sobre influência direta e indireta de vários aspectos situados em escala tanto externa quanto interna ao parque.

A nível local e regional, existem fragilidades e oportunidades de aprimoramento que refletem na visitação e utilização dos equipamentos e atrativos do PEIT. Percebese que, de um modo geral, os problemas são semelhantes nos atrativos em estudo e que a solução provém de uma melhor organização e planejamento da utilização destas instalações.

A sazonalidade da demanda de visitantes existente no PEIT dificulta a criação de um quadro fixo de funcionários voltados para o atendimento do público, uma vez que a mão-de-obra necessária em épocas de pico de visitação (como julho) é bem superior às épocas de baixa temporada. Isso ocasiona um déficit de pessoal e superávit em épocas distintas, que não podem ser solucionadas facilmente. 
Apesar das negatividades observadas, nota-se que uma estratégia de marketing e promoção poderia reverter em parte esta negatividade e transformar o parque em destino agregado aos dois pólos regionais de turismo histórico-cultural (Ouro Preto e Mariana), diferenciando-se destes a partir da ênfase de sua imagem na oferta de produtos e serviços relacionados ao turismo de natureza.

Isto ocasionaria um fluxo maior de visitantes distribuídos ao longo do ano, possibilitando a redução da sazonalidade, e conseqüentemente, reduziria a ociosidade das instalações a partir da otimização de seu uso. De certo, esta ação deveria ser executada junto com as outras propostas apresentadas, e então teríamos um aumento gradativo e regular dos índices de visitação.

A localização estratégica do Parque Itacolomi é um fator altamente positivo, já que a portaria do parque é limítrofe à zona urbana da cidade de Ouro Preto e está localizada a apenas $101 \mathrm{~km}$ da capital mineira Belo Horizonte, e a $14 \mathrm{~km}$ de Mariana. Há ainda a oportunidade de se abrir uma outra portaria, bem próxima à cidade de Mariana, o que contribuiria para a captação de um novo nicho de mercado regional.

Ademais, deve-se atentar para a necessidade de reposicionamento dos produtos e serviços do parque face às demandas emergentes, o que inclui a formatação de roteiros específicos para atender aos turistas nacionais e internacionais que estarão em Belo Horizonte durante a Copa do Mundo de 2014, haja vista que a capital mineira será uma das cidades-sede deste evento esportivo, e que o Itacolomi é o parque com melhor infraestrutura turística de Minas Gerais.

Projetos de incentivo ao turismo, dos governos estadual e federal, poderiam ser atraídos e aplicados em benefício da visitação pública do PEIT, como projetos vinculados ao Programa Destinos Indutores (Ministério do Turismo) e o Programa de Regionalização do Turismo, entre outros. Para tal, a gestão do parque deve reposicionar a marca Itacolomi no cenário regional e nacional. Isso diminuiria a dependência que a atual gestão do turismo no parque possui em relação aos recursos provenientes de compensações ambientais das grandes empresas de minério de ferro da região.

Para finalizar, destaca-se ainda a potencialidade de desenvolvimento de projetos de Extensão Universitária e Pesquisa Científica no parque. O campus principal da Universidade Federal de Ouro Preto (UFOP) localiza-se bem próximo à portaria do PEIT, com cursos de Turismo, Biologia, Geologia, Engenharia Ambiental, Economia, Museologia etc. A universidade e especificamente os cursos citados podem contribuir grandemente para o aprimoramento dos equipamentos e atrativos construídos do PEIT, seja através de projetos, estudos ou agregação de informações e práticas nestes equipamentos.

O roteiro de análise de equipamentos e atrativos construídos desenvolvido durante este projeto surgiu em decorrência da falta de modelos de análise deste porte que possibilitem a aplicação e obtenção de dados de forma específica, respeitando as peculiaridades de cada atrativo e situação. Este modelo pode ser utilizado como um 
Bedim, B.P., Campos, C.F.; Vidal, T.C.

gerador de dados específicos para a formulação de planejamentos condizentes com a realidade local.

\section{Referências Bibliográficas}

BEDIM, B.P. O Programa de Turismo do Parque Estadual do Itacolomi: Significados, Reflexos e Perspectivas no Âmbito Regional. In: Anais do Encontro Nacional de Turismo com Base Local. Curitiba: Ed. UFPR/ UNICENP, 2004. 16p.

BEDIM, B.P. O espaço capitalista da natureza e seu (contra) uso turístico: a dialética da visitação pública em áreas naturais protegidas - um ensaio teórico. Caderno de Turismo, Rio de Janeiro, (IVT-UFRJ), v. 7, n. 3, p.75-89, 2007.

BEDIM, B.P. O processo de intervenção social do turismo na Serra de Ibitipoca (MG): simultâneo e desigual, dilema camponês no "Paraíso do Capital". $406 \mathrm{f}$. Dissertação (Mestrado em Geografia). Belo Horizonte: IGC-UFMG, 2008.

BEDIM, B.P. O Parque Nacional da Serra da Canastra como epicentro de clusters turísticos embrionários. Tese de Doutorado/Projeto. Belo Horizonte: IGC-UFMG, 2010.

BEDIM, B.P.; RAMOS, M.V. Análise socioambiental do Programa de Turismo do Parque Estadual do Itacolomi (Protur-Peit). Ouro Preto: UFOP, Pró-Reitoria de Pós-Graduação e Pesquisa, 2004/2005. (Relatórios finais de pesquisa, volumes 1 e 2).

BEDIM, B.P.; TUBALDINI, M. A. S. Turismo e populações rurais do entorno de Unidades de Conservação: dilemas socioambientais entre diferentes formas de apropriação do território. Revista OLAM - Ciência \& Tecnologia, Rio Claro, v.6, n.2, p.356-376, dez. 2006.

BRASIL. Ministério da Indústria, Comércio e Turismo/ Ministério do Meio Ambiente. Diretrizes para uma política nacional de ecoturismo. Brasília: Embratur/lbama, 1994.

BRASIL. Lei Federal $n^{\circ}$ 9.985, de 18 de julho de 2000. Dispõe sobre o SNUC - Sistema Nacional de Unidades de Conservação.

COOPER, C. FLETCHER, J.; FYALL,A. Turismo: Princípios e Práticas, 3 ed. Porto Alegre: Bookman, 2002.

DANTAS,N.G.S.; MELO, R.S. O método de análise SWOT como ferramenta para promover o diagnóstico turístico de um local: o caso do município de Itabaiana / PB, Caderno Virtual de Turismo, Vol. 8, n.1 (2008).

EPLERWOOD International; SETUR (MG). Diagnóstico Turismo de Natureza: Destino Serra do Cipó. Belo Horizonte: SETUR, 2007. 
FREDERICO, I.B.; NEIMAN, Z. Infraestrutura sustentável para o Ecoturismo. In: NEIMAN, Z.; RABINOVICI, A. (Org). Turismo e Meio Ambiente no Brasil. Barueri: Manole, 2010. p.149-166.

GOELDNER, C.R.; RITCHIE, J.R.B.; MCINTOSH, R.W. Turismo: princípios, práticas e filosofias. Porto Alegre: Bookman, 2002.

INSTITUTO ESTADUAL DE FLORESTAS (IEF). Plano de Manejo do Parque Estadual do Itacolomi: Encartes 1 e 2, Planejamento e manual de gestão. Belo Horizonte: Instituto Estadual de Florestas (MG), Out. 2007.

INSTITUTO ESTADUAL DE FLORESTAS (IEF). Anteprojeto do Plano de Implantação e Manejo do Parque Estadual do Itacolomi. IEF/MG. Belo Horizonte, 1993.

INSTITUTO ESTADUAL DE FLORESTAS (IEF). Anteprojeto do Plano de Implantação do Parque Estadual do Itacolomi. IEF/MG. Belo Horizonte, 1986.

KOTLER, P.; KELLER, K. Administração de marketing. 12.ed. São Paulo: Prentice Hall Brasil, 2006.

MILLER, K. R. Em busca de um novo equilíbrio: Diretrizes para aumentar as oportunidades de conservação da biodiversidade por meio do manejo biorregional. Brasília: IBAMA, 1997.

NEIMAN, Z.; RABINOVICI, A. (Org). Turismo e Meio Ambiente no Brasil. Barueri: Manole, 2010. 332p.

SERRANO, C. (Org.). A educação pelas pedras. São Paulo: Chronos, 2000.

SPIX, W.V. Viagem pelo Brasil [1817,8]. São Paulo - Belo Horizonte: ItatiaiaPioneira, 1987.

TERRA, Consultoria e Assessoria em Estudos Geoambientais. Levantamento dos Aspectos históricos e culturais do Parque Estadual do Itacolomi: anexo II. Belo Horizonte, 1994.

\section{NOTAS:}

${ }^{1} \mathrm{~A}$ Serra do Espinhaço foi reconhecida como uma Reserva da Biosfera pela UNESCO em junho de 2005. Trata-se de áreas de ecossistemas terrestres e/ou marinhos reconhecidas pelo programa MaB/UNESCO como importantes em nível mundial para a conservação da biodiversidade e o desenvolvimento sustentável e devem servir como áreas prioritárias para experimentação e demonstração dessas práticas (MILLER, 1997). 
${ }^{2}$ De acordo com Bedim (2008), o Instituto Estadual de Florestas foi criado oficialmente em 05/01/1962, como uma autarquia vinculada à Secretaria de Agricultura de MG. Desde então, tornava-se atribuição do IEF a gestão dos Parques sob o domínio do Estado mineiro. A partir daí, abriram-se as perspectivas de criação de novos Parques Estaduais naquele período, como o Itacolomi (BEDIM, 2008, p.205).

${ }^{3} \mathrm{O}$ artigo de Bedim (2004) foi a primeira produção científica a analisar a visitação pública no Parque Estadual do Itacolomi, bem como o fluxo turístico a ela relacionado. $\mathrm{Na}$ época, o autor era monitor do parque e pôde acompanhar de perto a estruturação e a abertura do mesmo aos visitantes. Os relatórios do projeto de iniciação científica desenvolvido pelo autor na época, em parceria com o prof. Marcelo Viana Ramos, podem ser consultados nos arquivos da Pró-Reitoria de Pós-Graduação e Pesquisa da Universidade Federal de Ouro Preto (PROPP-UFOP), e contem dados interessantes sobre a atmosfera política e administrativa do projeto experimental de gestão compartilhada que subjaz à abertura do parque à visitação (BEDIM; RAMOS, 2004/2005).

${ }^{4}$ Segundo Bedim (2004, p.7), em 1818 o alemão Wilhilm vos Spix percorreu os arredores de Vila Rica, perpassando e descrevendo com ímpar sutileza aspectos da Serra do Itacolomi: "O Itacolomi é o mais alto píncaro da Serra de Ouro Preto, cujos declives para o sul formam com o morro de Vila Rica o estreito vale, onde está a cidade. Para subirmos a esse monte partimos do vale, de manhã, às oito horas, transpondo o Ribeirão de Ouro Preto, e chegamos ao meio-dia ao cume. O caminho leva por risonhas ladeiras de capim, às vezes por mata baixa no alto. Pouco a pouco, alarga-se a chapada do morro, e achamo-nos numa planície extensa, docemente inclinada e em cujo fundo se eleva o último píncaro de rocha" (SPIX, 1987, p.243).

${ }^{5}$ De acordo com o site cálculos.com, o ano de 2009 possuía até 12/09 a UFIR de 1,9372 real. Embora a UFIR - Unidade Fiscal de Referência - tenha sido extinta em 2000 para fins fiscais, entendemos que a mesma é um parâmetro de valores monetários. Fonte: http://www.calculos.com/consulta20.php?bd tabela=ufir

${ }^{6}$ Plano de manejo do PEIT (IEF, 2007).

${ }^{7}$ SWOT é uma sigla oriunda do inglês e é um acrônimo de Forças (Strengths), Fraquezas (Weaknesses), Oportunidades (Opportunities) e Ameaças (Threats).

${ }^{8}$ Fonte: http://pt.wikipedia.org (2010). 
${ }^{9}$ KOTLER, Philip; KELLER, Kevin. Administração de marketing.12.ed. São Paulo: 2006, p.50.

${ }^{10}$ Criado em 1967, até 2004 o parque era visitado pelos moradores sem fiscalização e após esta data, o acesso passou a ser pago e a estadia dos visitantes monitorada visando fim de abusos e excessos que, somados ao fim do sistema gratuito de transporte da portaria até a sede para a população (2004-2007), ajudou a incutir em parte da população uma má imagem da UC que repercute no serviço de guias locais de Ouro Preto. - relatos de visitantes afirmam que guias locais desincentivavam a visitação ao PEIT.-

${ }^{11}$ Denominamos aqui, macro-estrutura para toda a infra-estrutura do parque somada a infra-estrutura acessível ao turista nas proximidades do parque.

Bruno Pereira Bedim: Professor efetivo do Departamento de Turismo da UFOP. Email: brunobedim@yahoo.com.br Link para o currículo Lattes: http://lattes.cnpq.br/1654772916093941

Caiki Flaeschen de Campos: Graduando em Turismo pela UFOP - Universidade Federal de Ouro Preto.

Email: caikiflaeschen@yahoo.com.br

Link para o currículo Lattes: http://lattes.cnpq.br/0609863614529702

Tatiana Corrêa Vidal: Graduanda em Turismo pela UFOP - Universidade Federal de Ouro Preto.

Email: taticvidal@yahoo.com.br

Link para o currículo Lattes: http://lattes.cnpq.br/6512126951162603

Data de submissão: 09 de novembro de 2009.

Data do aceite: 09 de abril de 2010. 